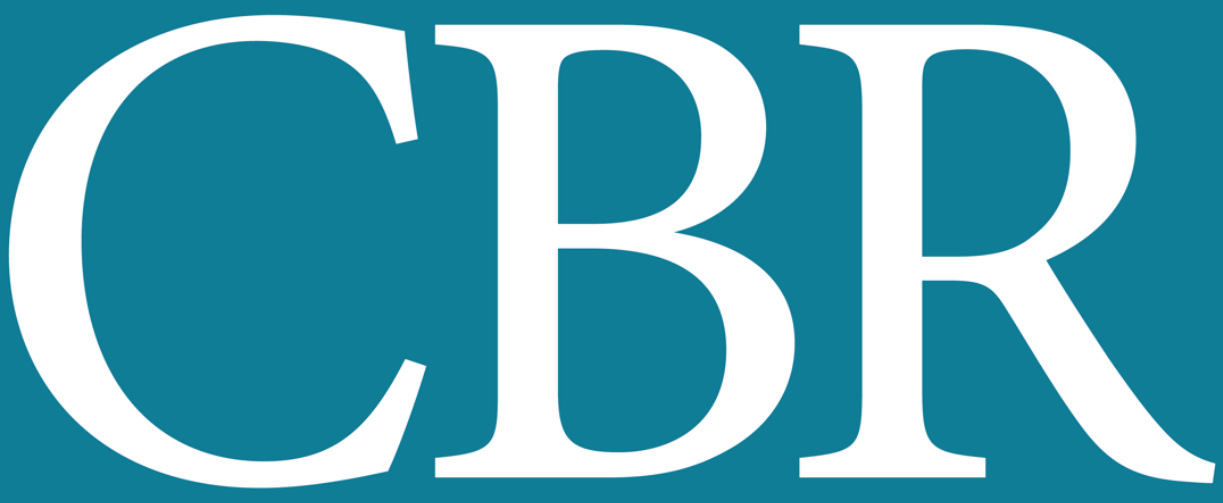

INTERNATIONAL JOURNAL OF CANCER AND BIOMEDICAL RESEARCH

https://jcbr.journals.ekb.eg

Editor-in-chief

Prof. Mohamed Labib Salem, PhD

Evaluation of the anticancer effect of violacein, phycocyanin and phycocyanobilin on apoptotic genes expression and glycan profiles in breast cancer cells

Neveen A. Hussein, Samia A. Ebied and Marwa M. Saleh 


\section{Welcome letter from Editor-in-Chief}

Welcome to the Int J Cancer and Biomedical Research (IJCBR)!

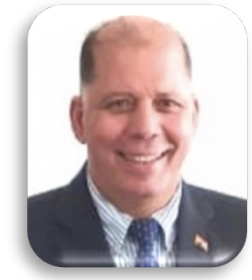

It is with great pleasure that I write this editorial to welcome you to the IJCBR. This journal provides a platform for publication of original and reviews research articles, short communications, letter to editor, thesis abstract, conference report, and case studies. These types of publication are directed at the interface of the fields of cancer and biomedical research.

The IJCBR relies on a distinguished expert of the Advisory and Editorial Board Members from the top international league covering in depth the related topics. They timely review all manuscripts and maintain highest standards of quality and scientific methodology and ethical concepts. Meanwhile, we take all possible means to keep the time of the publication process as short as possible.

I take this chance to welcome your contributions to the IJCBR and have every expectation that it will soon become one of the most respected journals in both the fields of cancer and biomedical research.

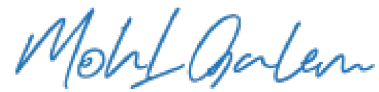

Mohamed L. Salem,

Editor in Chief 


\title{
Evaluation of the anticancer effect of violacein, phycocyanin and phycocyanobilin on apoptotic genes expression and glycan profiles in breast cancer cells
}

\author{
Neveen A. Hussein, Samia A. Ebied and Marwa M. Saleh \\ Applied Medical Chemistry Department, Medical Research Institute, Alexandria University, Egypt
}

Background: Cancer researchers have been concentrated on finding the best therapeutic strategies to decline cancer mortality rates. Marine natural products with pharmacological activities have potent anticancer activities. Aim: This study investigated the anticancer effect of violacein, phycocyanin, and phycocyanobilin in MCF-7 cells. Additionally, the elucidation of combined therapy efficiency (violaceinphycocyanin) on enhancing the anticancer activity of monotherapy. Materials and Methods: The cultured untreated, and treated cells by etoposide, violacein, phycocyanin, phycocyanobilin, and combined therapy were subjected to molecular studies, and glycan profiles by real time-PCR, and MALDI-TOF respectively. Results: $\mathrm{Bax}, \mathrm{BCl}-2$, caspase-3 genes expression, and $\mathrm{Bax} / \mathrm{Bcl}-2$ ratio in all groups were significantly upregulated compared to the untreated cells except for a significant decrease in $\mathrm{Bcl}-2$ by etoposide or combined therapy and an insignificant difference in Bax/Bcl-2 by PC or PCB treatment. The intensity of tetra-, tri-sialylated $\mathrm{N}$-glycan, and di-sialylated O-glycan was significantly decreased in violacein, and combinedtreated cells when compared to untreated or PC-treated cells. Mono-sialylated Oglycan was also decreased in combined therapy compared to the treated or untreated cells. Conclusion: Cotreatment with violacein/PC generated synergistic, antiproliferative, and pro-apoptotic effects on MCF-7 cells. Therefore, these compounds may be promising chemotherapeutic agents for breast cancer.

Keywords: Apoptotic genes; MALDI-TOF; N-/O-glycans; Real time-PCR.

Editor-in-Chief: Prof. M.L. Salem, PhD - Article DOI: 10.21608/jcbr.2021.46268.1079

\section{INTRODUCTION}

Breast cancer (BC) represents $25 \%$ of all the cancer cases and is recognized as the second mortality cause among women $(15 \%$ of all tumor deaths) (Ferlay et al., 2015). However, BC prevalence is high in developed countries, its mortality rates are rising in less developed areas (Ghoncheh et al., 2015). Although the new therapies advancement in the past decades, have improved $B C$ survival rate, the numbers of mortalities are still significant due to drug resistance by numerous mechanisms as altered proteins expression, and reduced apoptosis. Thus, it is necessary to search for new therapies with less resistance potential to allow BC treatment. Recently, marine natural products with pharmacological potentials have been revealed to have a potent anticancer effect and fewer toxic effects. Therefore, these products have valuable development and utilization (Yue et al., 2015).

Violacein, a unique violet pigment from Chromobacterium violaceum, has fascinated attention as an immunomodulator, antioxidant, antibacterial, antiviral, and antiprotozoal activities. Violacein potentially inhibits tumor initiation and induces apoptosis in various cancers (Alshatwi et al., 2016). Phycocyanin (PC) is a bio-active nutrient component extracted from various species, as Spirulina (Devanathan and Ramanathan, 2012) and has efficient hepatoprotective, anti-inflammatory, and free radicals-scavenger properties. It is even utilized in cosmetics and food coloring because it is nontoxic and non-carcinogenic (Romay and Gonzalez, 2000). PC polypeptide chain consists 
of the chromophore (phycocyanobilin, $\mathrm{PCB}$ ) and apoprotein. PCB is a linear tetrapyrrolic molecule which has bilirubin-like structure, a valuable antioxidant, and antiproliferative activities (Vitek and Schwertner, 2007).

Apoptosis is considered a favoring target for the anticancer therapy. The intrinsic/extrinsic pathways achieve apoptosis through cleavage of multiple proteins. The inhibition of apoptosis through overexpression of anti-apoptotic proteins and down-expression of pro-apoptotic proteins in cancer cells causes intrinsic resistance to the anticancer drugs (Pfeffer and Singh, 2018).

Glycosylation is post-translational protein modifications, where $\mathrm{N}$-and $\mathrm{O}$-glycans are the most common glycans attached to asparagine and serine/ threonine residues respectively (Brockhausen and Stanley, 2015). Generally, glycans have been detected on the cell surface,also, they participate in the interactions of cell-cell and cell-extracellular matrix. Glycans have a major role in cells growth, differentiation, pathogenesis, and innate immunity. In cancer, glycosylation modifications may control cancer development/progression, and offering novel targets for therapy (Varki, 2017). Consequently, this study examined the anticancer potential of natural products (violacein, phycocyanin, phycocyanobilin) on breast cancer cell line. Also, the elucidation of drug combination efficiency (violacein-phycocyanin).

\section{MATERIALS AND METHODS Cultivation of Spirulina platensis}

Loop full $S$. platensis (Biotechnology Department, Institute of Graduate Studies and Researches, Alexandria University) was inoculated in sterile Zarrouk's medium, growth for 15 days $\left(30 \pm 2^{\circ} \mathrm{C}\right)$ then filtrated and washed.

\section{Soluble proteins in Spirulina}

The liquid chromatography-mass spectrometrybased proteomic (LC-MS) included: protein extraction from samples, fractionation to remove contaminants, proteins digestion into peptides by trypsin mass-spectrometer grade, post-digestion separation to get the homogeneous mixture of peptides, and analysis by LC-MS using C-18 column. (Song et al., 2015).

\section{Preparation, characterization of PC, PCB}

Spirulina platensis cells were harvested by centrifugation (10000xg, $15 \mathrm{~min}$ ), adhere salt was removed by double distilled water, and then biomass was dried at $50 \circ \mathrm{C}$ and homogenized. Freezing/thawing in dark were repeated 3 times. Centrifugation at $10000 \times x$ for $20 \mathrm{~min}$. Absorbance was evaluated at 280 and $620 \mathrm{~nm}$ (Lambda 25 UV/VIS spectrometer, PerkinElmer, USA). The crude extract of PC was purified by fractional precipitation with ammonium sulphate (Saran et al., 2016) and characterized by SDS-polyacrylamide gel electrophoresis (SDS-PAGE), fourier-transform infrared spectroscopy (FT-IR), and spectroscopy measurement (UV-Visible absorption spectra) (Patel et al., 2005). The PCB was cleaved from protein with conc. $\mathrm{HCl}$ (Beuhler et al., 1976), ethanol then water were added, mixture was centrifuged at $12,000 \times$ for $5 \mathrm{~min}$ to extract the pigment into chloroform. The pigments were converted to their dimethyl esters and characterized by spectroscopic measurement (Schram and Kroes, 1979), mass spectrometry (MALDI-TOF) (Goetz et al., 2009) and FT-IR (Mohan, 2005).

Violacein (Sigma) was dissolved in dimethyl sulfoxide (DMSO) and characterized by UVVisible scanning (Ahmed et al., 2012), MALDITOF (Goetz et al., 2009), and FT-IR (Mohan, 2005).

\section{Cell culture}

Breast cancer-derived MCF-7 cells (RRID: CVCL_0031, Medical Research Institute, Alexandria University, Egypt) were cultured in a high glucose Dulbecco's Modified Eagle's Medium (DMEM) (Lonza, Belgium). All MCF-7 cell culturing was held in the humidified $\mathrm{CO}_{2}$ incubator at $37^{\circ} \mathrm{C}$ with a permanent atmosphere $\left(5 \% \mathrm{CO}_{2}\right.$ and $95 \%$ air). In all experiments, exponentially growing cells at 60 $80 \%$ confluence were used. Cells were thawed and propagated firstly before sub-cultures and drug treatment.

\section{Cell viability}

3-(4,5-dimethylthiazol-2-yl) -2,5diphenyltetrazolium bromide (MTT) was reduced to a purple formazan by mitochondrial dehydrogenases of viable MCF-7 cells 
(Mosmann, 1983). Cells ( $1 \times 10^{6}$ cells $/ \mathrm{mL}$ ) were plated and after an overnight growth, cells were treated with different concentrations of etoposide (Sigma) as conventional chemotherapeutic agent, positive control, (100, $50,25,12.5,6.25,3.125 \mu \mathrm{g} / \mathrm{ml})$, violacein (10, 5.0, 2.5, 1.25, 0.625, $0.3125 \mu \mathrm{g} / \mathrm{ml}), \mathrm{PC}(2.0,1.0$, $0.5,0.25,0.125,0.0625 \mathrm{mg} / \mathrm{ml})$, PCB (100.0, $50.0,25.0,12.5,6.25,3.125 \mu \mathrm{g} / \mathrm{ml})$, and combined of violacein $(2.5,1.25,0.625,0.3125$, $0.15625 \mu \mathrm{g} / \mathrm{ml})$ and $\mathrm{PC}(0.6,0.3,0.15,0.075$, $0.0375 \mathrm{mg} / \mathrm{ml}$ ). For untreated control, the cells were preserved in drug-free environment. After incubation for $48 \mathrm{~h}, 20 \mu \mathrm{L}$ MTT was added, incubated $4 \mathrm{~h}$ at $37^{\circ} \mathrm{C}$, centrifuged, and $100 \mu \mathrm{L}$ DMSO was added. Absorbance at $570 \mathrm{~nm}$ was assessed using a microplate reader (Bio-Rad, USA). Experiments were done in triplicate and their mean absorbance were calculated. The drug concentration equivalent to $50 \%$ inhibition of cell proliferation in drug-treated cells $\left(\mathrm{IC}_{50}\right)$ was determined.

\section{Combination index $(\mathrm{Cl})$ of violacein and PC}

$\mathrm{Cl}$ used for analysis the synergistic, antagonistic or additive effects of two drugs. $\mathrm{Cl}>1$ antagonism, $\mathrm{Cl}=1$ additive, $\mathrm{Cl}<1$ synergy effect (Chou and Talalayn, 1984).

$$
\mathrm{Cl}=\left[(D)_{1} /\left(D_{x}\right)_{1}\right)+\left((D)_{2} /\left(D_{x}\right)_{2}\right]
$$

$(D)_{1}=$ Concentration of the first drug which achieved an impact in combination.

$\left(D_{x}\right)_{1}=$ Concentration of the first drug which caused similar impact alone.

$(D)_{2}=$ Concentration of the second drug that achieved an impact in combination

$\left(D_{x}\right)_{2}=$ Concentration of the second drug which generated similar impact alone.

Relative quantification of $\mathrm{Bax}, \mathrm{Bcl}-2$, caspase-3 expression

\section{RNA extraction}

Total RNA was extracted from cultured cells ( $1 \times 10^{6}$ cells/well): untreated, and treated cells by $\mathrm{IC}_{50}$ of etoposide, violacein, $\mathrm{PC}, \mathrm{PCB}$ and combined violacein-PC $(0.63 \mu \mathrm{g} / \mathrm{ml}, 0.153$ $\mathrm{mg} / \mathrm{ml}$ respectively) for $48 \mathrm{~h}$, using RNeasy Mini Kit (Qiagen) according to the manufacture's instruction. The extracted RNA concentration was determined at $260 \mathrm{~nm}$ using NanoDrop Spectrophotometer (thermo Scientific, USA). The A260/A280 estimated RNA purity.

\section{Reverse transcription reaction}

QuantiTect Reverse Transcription Kit (Qiagen) was used for synthesis CDNA from total RNA using a PCR thermocycler (Applied Biosystem, Foster City, USA). The reactions contained 10 pg-1 $\mu$ g template RNA, $4 \mu$ l Quantiscript RT Buffer, $2 \mu \mathrm{l}$ gDNA Wipeout Buffer, $1 \mu \mathrm{l}$ Quantiscript Reverse Transcriptase, $1 \mu \mathrm{l}$ RT primer mix, and RNase-free water.

\section{Real-time PCR}

The genes expression was analyzed on real-time PCR (Stratagene MX3000, USA) using $2 \mu \mathrm{l}$ Template cDNA, $1 \mu \mathrm{l}$ TaqMan primer/probe (Applied Biosystem), 10 $\mu$ l oasigTM 2x qPCR Master Mix (Qiagen) and 7 $\mu$ l DNase-RNase-free water. The reaction mixtures were initially activated at $95^{\circ} \mathrm{C}$ for $30 \mathrm{sec}$, followed by 40 cycles at $95^{\circ} \mathrm{C}(5 \mathrm{sec}), 60^{\circ} \mathrm{C}(30 \mathrm{sec})$, and $72^{\circ} \mathrm{C}(60$ $\mathrm{sec})$ and then final extension at $72^{\circ} \mathrm{C}(10 \mathrm{~min})$. The TaqMan Assays used: Bax (ID\#Hs01016548_g1), Bcl-2 (ID\#Hs01048932_g1), caspase-3 (ID\#Hs00234387_m1) and GAPDH "housekeeping gene" (ID\#Hs99999905_m1). The relative quantification (RQ) of genes expression was estimated using comparative cycle threshold $\mathrm{Ct}\left(2^{-\Delta \Delta C t}\right)$.

BAX :

forward primer (FP) 5'-TGGCAGCTGACATGTTTTCTGAC-3' reverse primer (RP) $5^{\prime}$-TCACCCAACCACCCTGGTCTT- $3^{\prime}$

BCl-2: FP 5'-TCGCCCTGTGGATGACTGA-3' RP 5'-CAGAGACAGCCAGGAGAAATCA-3',

Caspase-3: FP 5'-GGACAGCAGTTACAAAATGGATTA-3' RP 5'-CGGCAGGCCTGAATGATGAAG-3'

GAPDH: FP $5^{\prime}$-TGA AGGTCGGAGTCAACGGATTTGGT-3' RP 5'-CATGTGGGCCATGAGGTCCACCAC-3'

\section{Glycan profiles}

Preparation of MCF-7 protein powder

The harvested cells $(100 \mu \mathrm{l})$; untreated, and treated with violacein $\left(\mathrm{IC}_{50}\right), \mathrm{PC}\left(\mathrm{IC}_{50}\right)$, and combined violacein-PC $(0.63 \mu \mathrm{g} / \mathrm{ml}, 0.153$ $\mathrm{mg} / \mathrm{ml}$ respectively); were homogenized in cold methanol (50\%). The homogenate has been adjusted to $4: 8: 3$ of chloroform/methanol /water, extracted at $37^{\circ} \mathrm{C}$ for $2 \mathrm{~h}$, then centrifuged for $15 \mathrm{~min}$ at $3000 \mathrm{rpm}$. The resultant pellets had been dried to yield a protein powder (Talabnin et al., 2016). 


\section{Preparation of $\mathrm{N}$-glycans}

The cells protein powder (1 $\mathrm{mg})$ was resuspended in $25 \mathrm{mM}$ ammonium bicarbonate. $\mathrm{N}$-glycans were enzymatically released through adding $5 \mathrm{mU}$ peptide: $\mathrm{N}$ glycosidase F (PNGase F) (Mechref et al., 2009) then incubated overnight $\left(37^{\circ} \mathrm{C}\right)$.

\section{Solid-Phase extraction of $\mathrm{N}$-glycans}

Glycans volume was adjusted by deionized water to $1 \mathrm{~mL}$. First, the mixture had been applied to C18 Sep-Pak cartridge (Waters, Milford, MA) and circulated 5 times. O-linked glycopeptides and peptides were held on this cartridge, and the released glycan was gathered as eluents, then cartridge was washed by deionized water. Eluents that contain the released $\mathrm{N}$-glycans were applied to activated charcoal microcolumns (Harvard Apparatus, Holliston, MA) that preconditioned with acetonitrile (ACN) and trifluroacetic acid (TFA), then the microcolumn was washed with TFA. Samples were eluted with $50 \%$ ACN that contains $0.1 \%$ TFA. Lastly, purified N-glycans were evaporated until dry by using vacuum CentriVap Concentrator (Labconco Corporation, Kansas City) then permethylated (Kang et al., 2008).

\section{Preparation of O-glycans}

The cells protein powder (1 mg) was exposed to reductive $\beta$-elimination at $45^{\circ} \mathrm{C}(100 \mathrm{mM} \mathrm{NaOH}$, that contains $1.0 \mathrm{M} \mathrm{NaBH}_{4}$ ) for $18 \mathrm{~h}$. The mixture was neutralized by $10 \%$ acetic acid and was desalted on AG50W-X8 $\left(\mathrm{H}^{+}\right)$column (Talabnin et al., 2016). The materials were eluted with $5 \%$ acetic acid. Boric acid was removed by evaporation with methanol. The released $\mathrm{O}$-glycans had been purified by $\mathrm{C} 18$ Sep-Pak cartridge column and permethylated (Mechref et al., 2009).

\section{Matrix-assisted laser desorption ionization/time of flight mass spectrometry instrumentation}

Purified N-/O-glycans (permethylated) were resuspended in methanol: water solution (50:50), containing $2.5 \mathrm{mM}$ sodium acetate. Sample $(0.5 \mathrm{~mL})$ was spotted on the MALDI plate directly and blended with an equal quantity of 2,5 dihydroxybenzoic acid-matrix.
The MALDI plate was dried under vacuum. Mass spectra were obtained utilizing MALDI TOF/TOF analyzer (Applied Biosystems, Framingham, MA) (Kang et al., 2005).

\section{Morphological Changes}

The nuclear morphology was investigated using an inverted microscope in untreated and all treated cells. Additionally, the scanning electron microscope was done to show the impact of violacein and/or PC on cell morphology. Transmission electron microscopy (TEM) for untreated and violacein-PC-treated cells was done.

\section{Statistical analysis}

The data were evaluated statistically using IBM SPSS software package version 20. KolmogorovSmirnov test was applied to verify the normality of distribution. One-way analysis of variance (ANOVA) and then Tukey's test were utilized to compare difference among groups. A correlation was assessed applying Spearman's coefficient. $\mathrm{P}<0.05$ was considered significant.

\section{RESULTS \\ Characterization of PC}

As shown in Figure (1), the major protein in $S$. platensis was PC where its efficiency by $0.1 \mathrm{M}$ sodium phosphate buffer $(122 \pm 4.35 \mathrm{mg} / \mathrm{g})$ was higher than that of double-distilled water $(64 \pm 5.03 \mathrm{mg} / \mathrm{g})$. Also, PC purity ratio was improved to a considerable level and had been increased to 2.55. SDS-PAGE indicated the presence of two bands corresponded to the two subunits of PC with molecular weights nearly 15 and $24 \mathrm{kD}$. UV-Visible scanning: The purified PC spectra demonstrated a prominent peak at 620 $\mathrm{nm}$, which was higher than crude extract. The peak intensity at $280 \mathrm{~nm}$ was low. FT-IR spectra: The protein-specific amide I band at $1655 \mathrm{~cm}^{-1}$ ( $\mathrm{C}=\mathrm{O}$ stretching) and amide II at $1547 \mathrm{~cm}^{-1}$. Shape and position of amide I band were employed for protein secondary structure analysis. The sharp amide I band for PC (at 1655 $\mathrm{cm}^{-1}$ ) indicated $\alpha$-helix as the main element of its secondary structure.

\section{Characterization of РСB}

UV-Visible scanning: The spectrum was characterized by maximum absorption at 365.5 $\mathrm{nm}$. FT-IR spectra: The existence of quite strong 
hydrogen bonds in the acid was specified by the broad $\mathrm{O}-\mathrm{H}$ and $\mathrm{N}-\mathrm{H}$ absorption bands between 3000 and $3500 \mathrm{~cm}^{-1}$. Mass spectra: The exact mass of dimethyl ester was 614 (Figure 2a).

\section{Characterization of violacein}

UV-Visible scanning: Absorption spectrum was showed maximum absorption at $585 \mathrm{~nm}$. FT-IR spectra: It showed all the distinctive signals. The band at $1648 \mathrm{~cm}^{-1}$ related to carbonyl $(C=0)$ stretching frequency. Moreover, a broad peak at $3475 \mathrm{~cm}^{-1}$ could be attributed to $\mathrm{NH}$ group on the indole nucleus. Mass spectrum: In the negative ion electrospray ionization-mass spectrometry (ESI-MS) spectrum, a quasimolecular ion peak was detected at $\mathrm{m} / \mathrm{z} 342.34$ $(\mathrm{M}-\mathrm{H})^{-}$(Figure 2b).

\section{Cell viability}

All concentrations of studied compounds were capable to inhibit the proliferation of cancer cells significantly $(p<0.001)$ except cells treated with $0.3125 \mu \mathrm{g} / \mathrm{ml}$ violacein which showed insignificant difference $(p=0.643)$ (Figure $3, A$ E). The $I C_{50}$ values were $34.22 \mu \mathrm{g} / \mathrm{ml}(58 \mu \mathrm{M})$, $0.8 \mu \mathrm{g} / \mathrm{ml}(2.30 \mu \mathrm{M}), 1.56 \mathrm{mg} / \mathrm{ml}(37 \mu \mathrm{M})$, and $96.0 \mu \mathrm{g} / \mathrm{ml}(163 \mu \mathrm{M})$ for etoposide, violacein, $\mathrm{PC}, \mathrm{PCB}$ respectively. The violacein $\mathrm{IC}_{50}$ was the lowest among all studied compounds. The violacein-PC combination had a synergistic effect at concentrations less than $1.25 \mu \mathrm{g} / \mathrm{ml}$ and $0.3 \mathrm{mg} / \mathrm{ml}$ of violacein and PC respectively.

\section{Morphological results}

Inverted light microscope: The treated cells were shifted from the spindle and elongated to a rounded shape. The monolayer cells turned into a rounded up, losing contact with neighboring cells, and were mostly detaching from the culture plate and floating in the medium. Cells showed shrinkage and size reduction when compared to the untreated cells that were well-spread with a flattened morphology. Also, the number of treated cells was decreased.

Scanning electron microscope: Untreated cells were firmly adherent. The cell surface demonstrated several links between the plasma membrane of neighboring cells and extended in all directions. Cells treated with violacein and/or PC showed shrinkage, and cell membrane abnormalities with membrane blebbing.

TEM: Untreated cells showed a rounded shape, a normal nucleus with microvilli like processes over the cells surface. The appearance of cell membrane abnormalities, cytoplasmic vacuoles, apoptotic bodies, and disappearance of microvilli was observed in combined-treated cells (Figure 4).

\section{Molecular parameters}

As revealed in Table 1 , and Figures 5,6, Bax, Bcl2 , caspase-3 expression, and $\mathrm{Bax} / \mathrm{Bcl}-2$ ratio in all groups were significantly higher than untreated group $(P=<0.001,0.002,0.001$ and 0.022 ) except a significant decrease in $\mathrm{Bcl}-2$ expression by treatment with etoposide $(P=0.001)$ or combined therapy $(P=<0.001)$ and an insignificant difference in $\mathrm{Bax} / \mathrm{Bcl}-2$ by $\mathrm{PC}$ or $P C B$ treatment $(P=1.000)$.

Comparing with etoposide-treated cells, Bax expression in the violacein-treated group was significantly upregulated $(P=0.001)$. While in $P C$ and PCB-treated groups, it was significantly downregulated $(P=0.002$ and $<0.001)$ and in the combined-treated group, it showed insignificant difference $(P=0.854)$. Bcl-2 expression was significantly upregulated in violacein, $P C, P C B$-treated cells $(P=<0.001)$. While combined-treated cells showed insignificant difference $(\mathrm{P}=0.999)$. Bax/Bcl-2 ratio was significantly downregulated in violacein, $P C, P C B$-treated cells $(P=<0.001)$. While combined-treated cells showed insignificant difference $(P=1.000)$. Caspase-3 expression was significantly downregulated in PC, PCB, and combined-treated cells $(P=<0.001)$. While violacein-treated cells showed insignificant difference $(P=0.999)$.

All studied parameters in PC, PCB, and combined-treated cells were significantly lower than the corresponding levels in violaceintreated cells $(P=<0.001,0.002,0.025,0.010)$ except $\mathrm{Bax} / \mathrm{Bcl}-2$ ratio which was significantly high in combined-treated cells $(P=<0.001)$.

A significant decrease in all genes in PCB-treated cells when compared to PC-treated cells $(\mathrm{P}=0.001,<0.001,0.004)$ except $\mathrm{Bax} / \mathrm{Bcl}-2$ which showed insignificant difference $(P=1.000)$. In combined-treated cells, Bax and $\mathrm{Bax} / \mathrm{Bcl}-2$ were 
significantly higher $(\mathrm{P}=0.049,<0.001)$, while $\mathrm{Bcl}-$ 2 expression was significantly lower $(P=<0.001)$ as compared to PC, and PCB-treated cells. Also, caspase-3 was significantly lower than PCtreated cells only $(P=0.009)$. A positive significant correlation between all studied parameters $(P=0.030,0.001,0.008,<0.001$, 0.046 ) except a negative significant correlation between $\mathrm{Bcl}-2$ and $\mathrm{Bax} / \mathrm{Bcl}-2 \quad(r=-0.650$, $\mathrm{P}=<0.001$ ) was observed.

\section{Glycan mass profiles}

The exact glycans compositions of hexose (Hex), deoxyhexose (dHex), N-acetylhexose (HexNAc), and $\mathrm{N}$-acetylneuraminic (sialic acids, NeuAc) were recognized based on their accurate masses (Figure 7; Table 2). The intensity of tetra-, tri-sialylated $\mathrm{N}$-glycan and di-sialylated O-glycan (structure 1,2) was significantly decreased in violacein and combined-treated cells when compared to either untreated or PCtreated cells $(\mathrm{P}=<0.001,0.002)$. Furthermore, mono-sialylated O-glycan (structure3) was significantly decreased in combined-treated cells when compared to untreated, violacein or PC-treated cells ( $P=0.003,0.045,0.004)$.

In PC-treated cells, all glycans structures showed insignificant difference compared to untreated or violacein-treated cells. Except for structures 1, 2 of both glycans, they were significantly higher than the corresponding intensity in violacein-treated cells $(P=<0.001$, 0.002 ). However, a significant decrease of $\mathrm{N}$ glycan structure 2 when compared to untreated cells $(P=0.007)$ and $N$-glycan structure 5,7 when compared to violacein-treated cells $(P=<0.001)$.

Treatment with violacein and/or PC did not affect $\mathrm{N}$-glycan structures 4, 6, 8. Conversely, structures 5, 7 in violacein-treated cells were significantly higher than untreated cells and in combined-treated cells than untreated or PCtreated cells $(P=<0.001)$.

\section{DISCUSSION}

Most of the natural products have a role in fighting malignancies and initiating identical cellular responses associated with synthetic drugs. Accordingly, these products may be used as potentially chemopreventive/ chemotherapeutic agents (Demain and Vaishnav, 2012).
All studied compounds reduced viability of viable MCF-7 cells in a dose-dependent manner. Etoposide had antiproliferative activity on MCF7 viability. Etoposide bonded to tubulin and interacted with topoisomerase II, causing chromosomal disruption. It stabilized covalent enzyme-cleaved DNA compounds, producing permanent DNA breaks as well as apoptosis (Dwarakanath et al., 2004). Also, violacein markedly reduced the viability of the cells. The divergences in its $\mathrm{IC}_{50}$ value from other studies suggested the presence of various cell-typespecific mechanisms that operate in the existence of violacein. (Alshatwi et al., 2016, Santhosh and Muthusamy, 2017). The violacein antiproliferative effect achieved by reactive oxygen species (ROS) production in cancer, causing apoptosis promoting via enhances of intracellular calcium and release of cytochrome c (De Carvalho et al., 2006).

The current results proved PC had antiproliferative effects on cells. These results were in line with a previous study (Jiang et al., 2019). The discrepancy in $P C I C_{50}$ value from other studies might be attributed to the effectiveness of PC that was greatly dependent on the origin of the organism, methods of extraction, purification, and storage. Also, as a protein, PC had poor stability, easy degradation, and temperature sensitivity (Gantar et al., 2012). Jiang et al. (2018) indicated that PC might efficiently prevent cell proliferation, induce tumor G0/G1 cell cycle arrest and trigger cell death in a dose-dependent manner.

Additionally, PCB had antiproliferative activity on MCF-7. The PC's pharmacological actions were exerted by its chromophore $\mathrm{PCB}$ since after $\mathrm{PC}$ administration in vivo, $\mathrm{PC}$ should be proteolytically degraded to $\mathrm{PCB}$ or PCB-linked peptides. The $P C B$ antiproliferative effect on cancer cells was attributed to their effective antioxidant activity, and inhibition of ROS production (Konícková et al., 2014).

Interestingly, the combination of violacein and PC created a synergistic anticancer effect on MCF-7. The combined therapy improved the efficacy when compared to monotherapy since they targeted crucial pathways in the synergy or an additive manner. 
Table 1. Statistical analyses of Bax, Bcl-2, caspase-3 expression and Bax/Bcl-2 ratio in MCF-7 cell line in different studied groups $(n=9)$

\begin{tabular}{|l|c|c|c|c|c|c|}
\hline & $\begin{array}{c}\text { Untreated } \\
\text { cells }\end{array}$ & $\begin{array}{c}\text { Etoposide- } \\
\text { treated cells }\end{array}$ & $\begin{array}{c}\text { Violacein- } \\
\text { treated cells }\end{array}$ & $\begin{array}{c}\text { PC-treated } \\
\text { cells }\end{array}$ & $\begin{array}{c}\text { PCB-treated } \\
\text { cells }\end{array}$ \\
\hline Bax & $1.04 \pm 0.3$ & $4.51 \pm 0.3^{\mathrm{a}}$ & $8.47 \pm 1.2^{\mathrm{ab}}$ & $3.30 \pm 0.4^{\mathrm{abc}}$ & $2.0 \pm 0.16^{\mathrm{abcd}}$ & $4.17 \pm 0.7^{\mathrm{acde}}$ \\
\hline Bcl-2 & $1.06 \pm 0.4$ & $0.56 \pm 0.1^{\mathrm{a}}$ & $3.24 \pm 0.20^{\mathrm{ab}}$ & $2.78 \pm 0.3^{\mathrm{abc}}$ & $1.90 \pm 0.2^{\mathrm{abcd}}$ & $0.52 \pm 0.1^{\mathrm{acde}}$ \\
\hline Caspase-3 & $1.11 \pm 0.5$ & $5.52 \pm 0.6^{\mathrm{a}}$ & $5.45 \pm 0.7^{\mathrm{a}}$ & $2.98 \pm 0.5^{\mathrm{abc}}$ & $2.07 \pm 0.2^{\mathrm{abcd}}$ & $2.14 \pm 0.4^{\mathrm{abcd}}$ \\
\hline Bax/Bcl-2 & $1.06 \pm 0.4$ & $8.24 \pm 1.0^{\mathrm{a}}$ & $2.61 \pm 0.3^{\mathrm{ab}}$ & $1.20 \pm 0.2^{\mathrm{bc}}$ & $1.06 \pm 0.2^{\mathrm{bc}}$ & $8.17 \pm 1.6^{\mathrm{acde}}$ \\
\hline
\end{tabular}

The results were expressed as mean \pm S.D, $n$ : number of samples in each group, ANOVA test, pairwise comparison between every 2 groups was performed utilizing Post Hoc Test (Tukey), a : comparing with untreated cells. ${ }^{\text {b}}$ : comparing violacein, PC, PCB, combined-treated cells with etoposide-treated cells, c: comparing PC, PCB, combined-treated cells with violacein-treated cells, d: comparing PCB, combined-treated cells with PC-treated cells, e: comparing combined-treated cells with PCB-treated cells, abcde: Significant at $\mathrm{P}<0.05$.

Table 2. Major N-and O-glycan structures in MCF-7 cell line.

\begin{tabular}{|c|c|c|c|}
\hline Glycans & $\mathrm{m} / \mathrm{z}$ & Glycan structure & Glycan Composition \\
\hline \multicolumn{4}{|c|}{ N-glycans } \\
\hline 1 & 4587.59 & $\because:=$ & HexNAc6Hex7 dHex1NeuAc4 \\
\hline 2 & 4226.54 & $\because>0=$ & HexNAc6Hex7dHex1NeuAc3 \\
\hline 3 & 2966.36 & $\because-a_{0}: \bar{\prime}$ & HexNAc4Hex5dHex1NeuAc2 \\
\hline 4 & 2395.27 & $a-0-0-90=1$. & HexNAc2Hex9 \\
\hline 5 & 2191.32 & $\underset{0-0-0-0}{a-0-a} \cdot 1$ & HexNAc2Hex8 \\
\hline 6 & 1987.53 & $a-a-a=$ & HexNAc2Hex7 \\
\hline 7 & 1783.62 & $a=$ & HexNAc2Hex6 \\
\hline 8 & 1579.36 & $a_{0-0}^{a-a} \cdot 1$ & HexNAc2Hex 5 \\
\hline \multicolumn{4}{|c|}{ O-glycans } \\
\hline 1 & 1706.23 & $\because-9$ & HexNAc2Hex2 NeuAc2 \\
\hline 2 & 1256.34 & .0 & HexNAc1Hex1 NeuAc2 \\
\hline 3 & 895.25 & 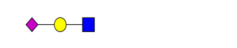 & HexNAc1Hex1NeuAc1 \\
\hline
\end{tabular}

This approach possibly reduced drug resistance and concomitantly provided therapeutic anticancer advantages as decreasing tumor progression, metastasis, cancer stem cell, and inducing apoptosis (Mokhtari et al., 2017).

In the current study, by using etoposide treatment, all parameters were upregulated except Bcl-2 which was downregulated. Etoposide may have cytotoxic functions through ROS induction, Akt/mTOR signaling stimulation, and caspase-3 activation (Zhang and Huang., 2013). Moreover, etoposide may cause doublestrand breaks accumulation in the cell's nuclei. Cells can identify these injure and sequentially eliminate the damaged cells by apoptosis (Jiang et al., 2015).

Bcl-2 family proteins have a significant role in promoting or inhibiting cells apoptosis, particularly mitochondrial pathway. Bcl-2 controls this pathway via blocking cytochrome $\mathrm{c}$ release and caspases activation. This mechanism confers $\mathrm{Bcl}-2$ exert the protective effect versus etoposide-induce apoptosis. While Bax, an agonist of apoptosis by enabling cytochrome $c$ release and activating caspases. A balance between anti-and pro-apoptotic members performs a crucial responsibility in deciding cell survival or death (Jiang et al., 2015). 

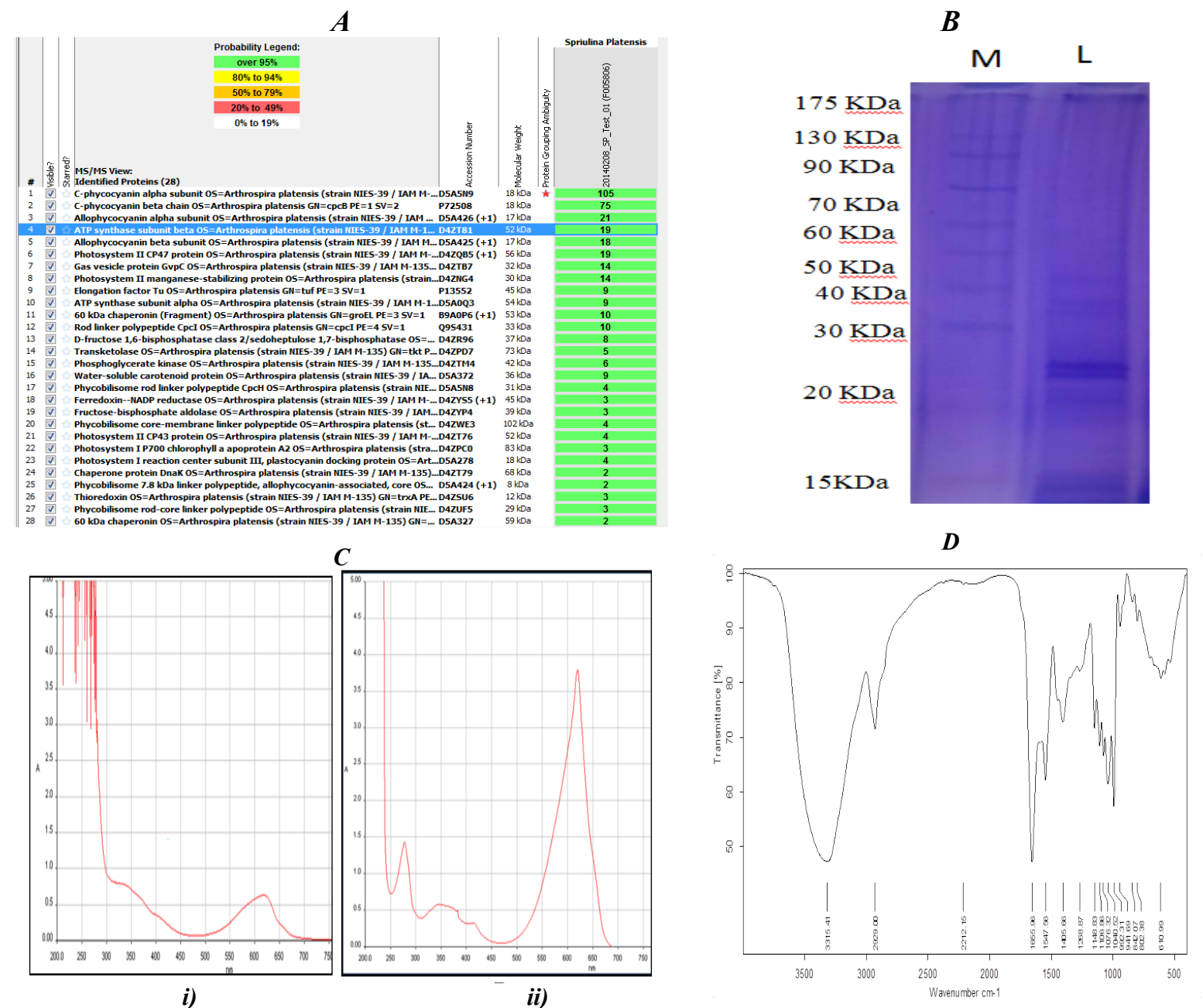

Figure 1. (A) LC-MS of S. platensis, (B) SDS-PAGE purification of PC, (C) absorption spectrum of (i) PC crude extract, (ii) purified PC, (D) FT-IR of purified PC.

Accordingly, the high ratio of $\mathrm{Bax} / \mathrm{Bcl}-2$ detected may be due to high Bax and low $\mathrm{Bcl}-2$ expression in the same cells. These alterations in genes expression by etoposide may be contributed to its increased cytotoxicity.

The significant increase of pro-apoptotic genes (Bax, caspase-3) in all groups and the significant decrease of anti-apoptotic gene (Bcl-2) in etoposide and combined therapy groups compared to untreated cells may indicate that these natural products can play an important role in promoting cells susceptibility to apoptosis. Consequently, this alternation leads to varying $\mathrm{Bax} / \mathrm{BCl}-2$ ratio which significantly increased in etoposide, violacein, and combined treated-cells. The altered ratio was skewed to a greater extent to apoptosis and may have been responsible for membrane potential reduction, cytochrome c leakage and associated downstream events of apoptosis as endonucleases and caspases activation. Furthermore, caspase- 3 activation led to cellular substrates cleavage and finally cell death (Wen et al., 2019).

Alternatively, $\mathrm{BCl}-2$ expression in violacein, $\mathrm{PC}$, PCB-treated cells was higher than untreated or etoposide-treated cells. These results seem contradictory to its apoptotic regulatory function so the overexpression may be attributed to the molecular machinery effort of cells to survive and escape the apoptosis pathway (Sagar et al., 2014).

As compared to etoposide-treated cells, violacein revealed a significant overexpression in Bax expression, whereas an insignificant difference in caspase-3. Also, the combined therapy showed insignificance difference in Bax, $\mathrm{Bcl}-2$ and their ratio. These results may indicate that etoposide, violacein and combined therapy have a comparable effect which resulted in the 

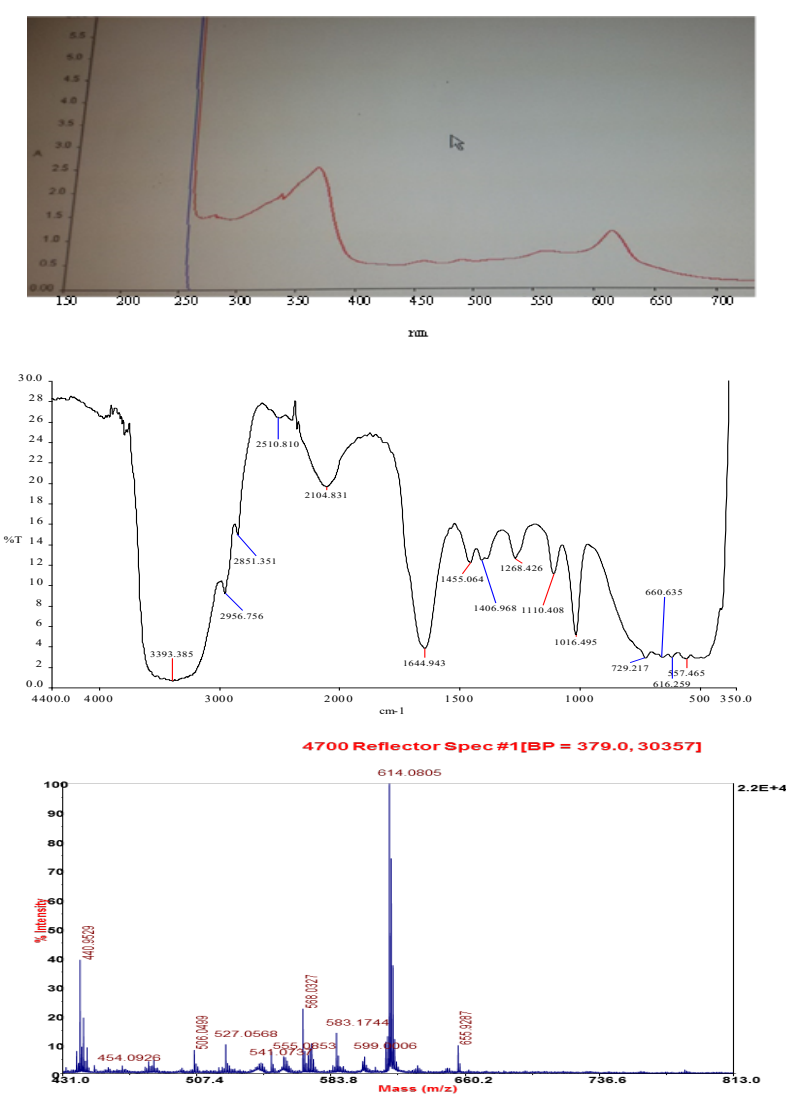

a)
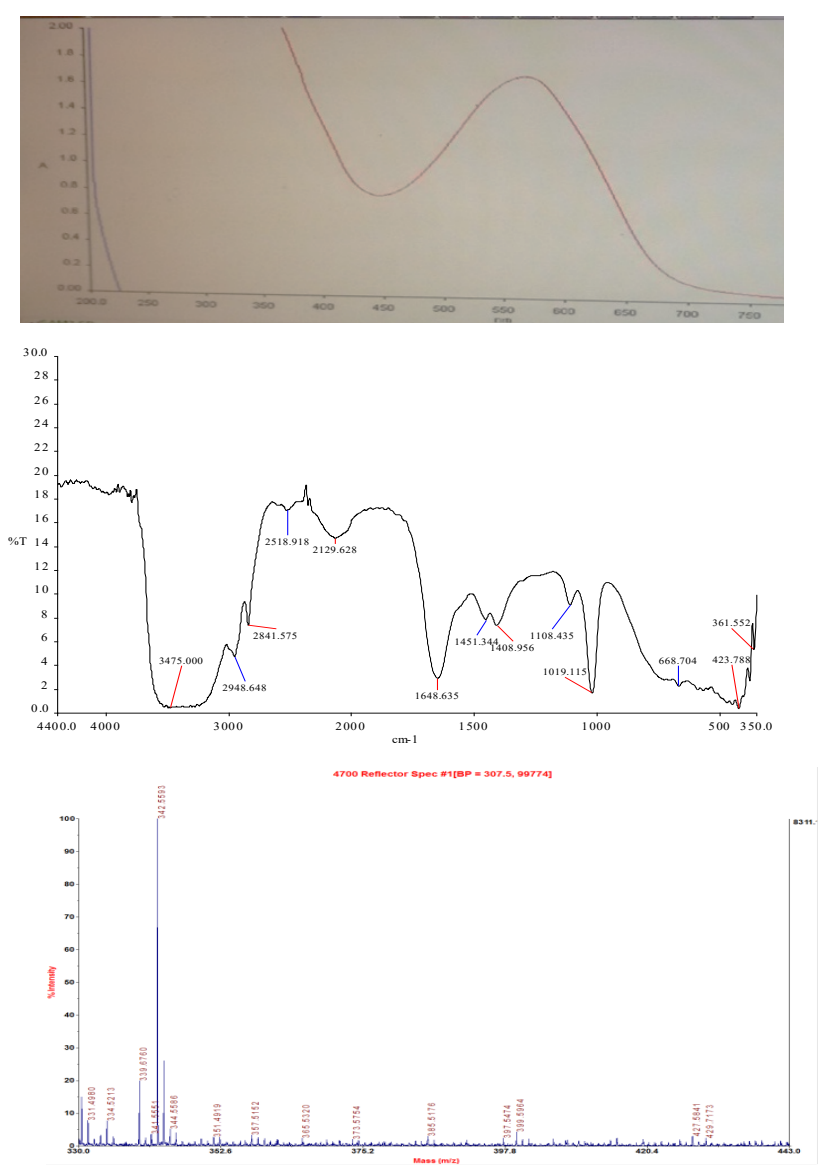

b)

Figure 2. UV-Visible scanning, FT-IR, and mass spectrum for (a) PCB, (b) violacein
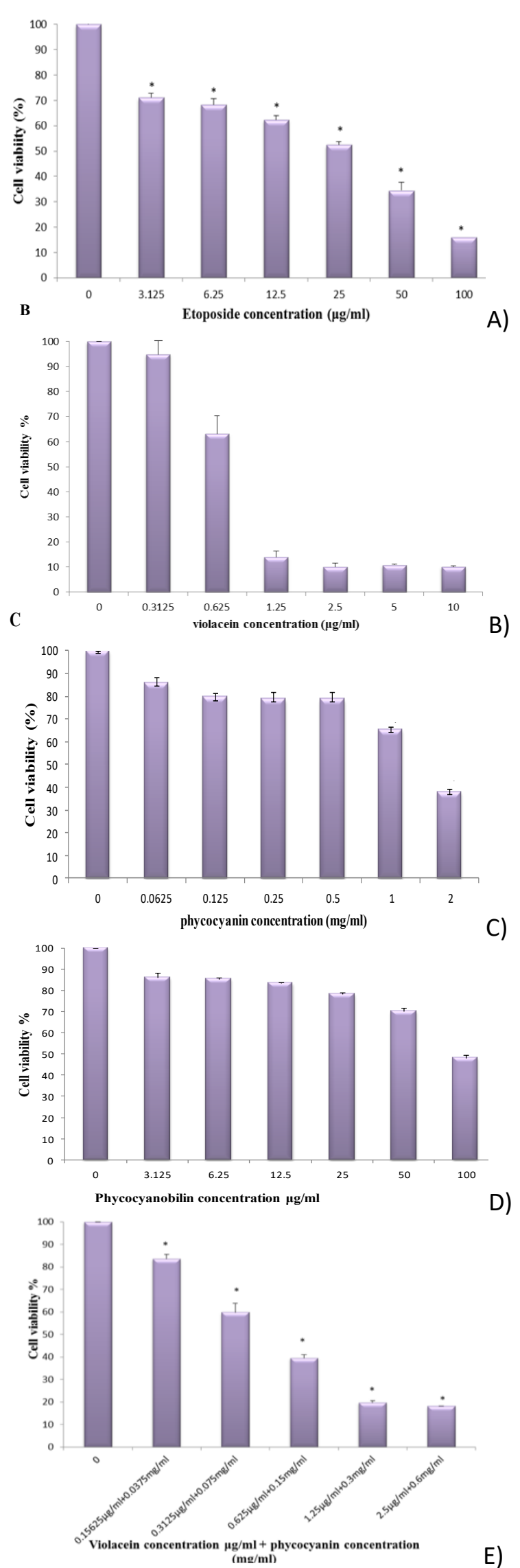

Figure 3. Viability \% of untreated and treated MCF-7 cells with different concentration (A) etoposide, (B) violacein, (C) PC, (D) PCB, (E) combined therapy (violacein-PC). 
1)

A

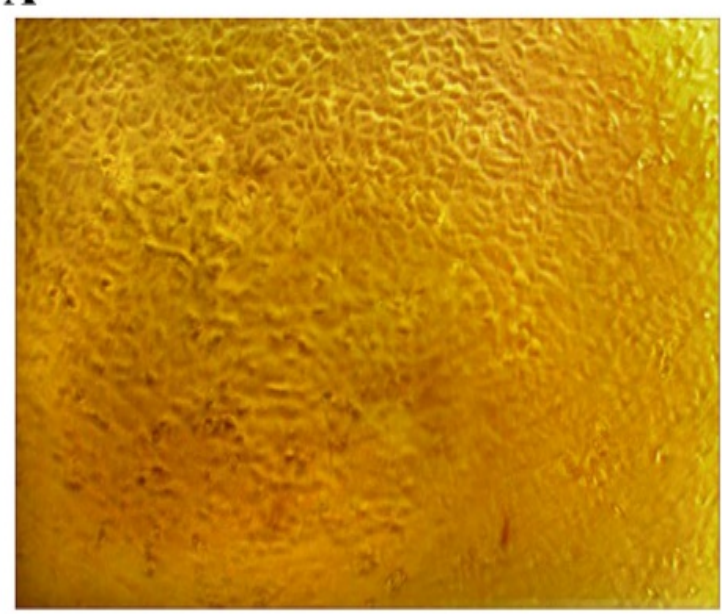

C

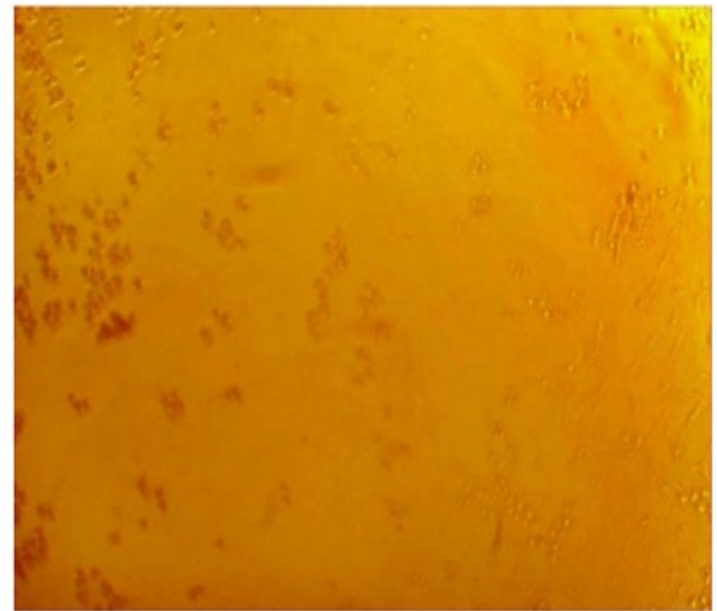

E

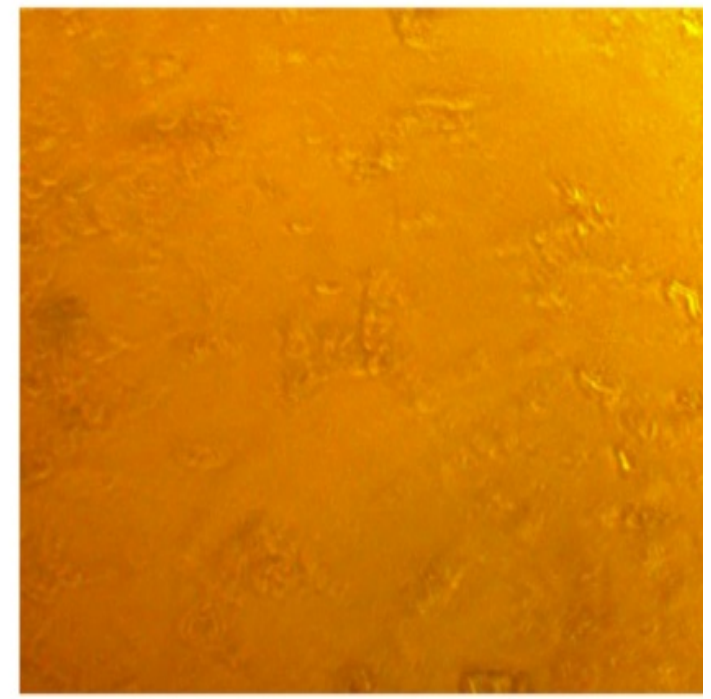

B

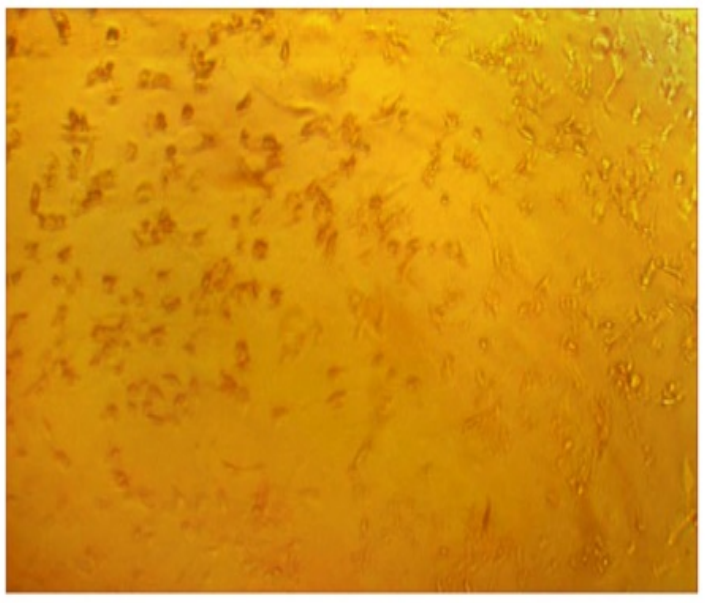

D

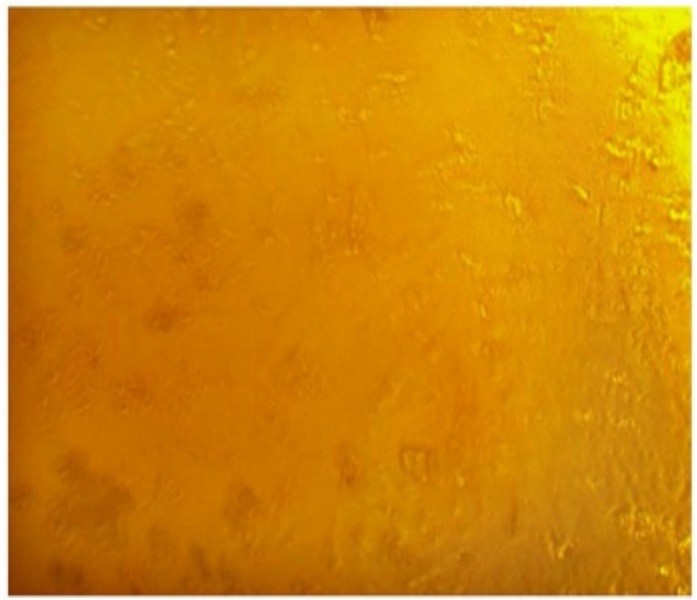

F

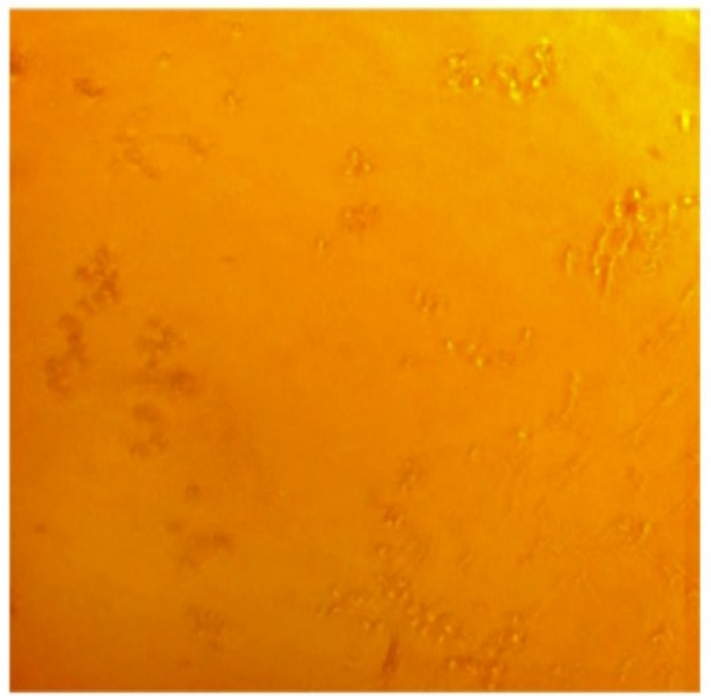


2)

$\mathbf{A}$

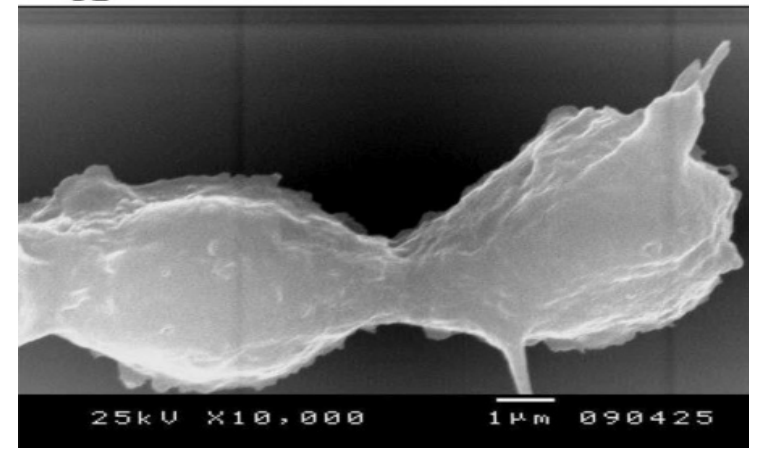

C

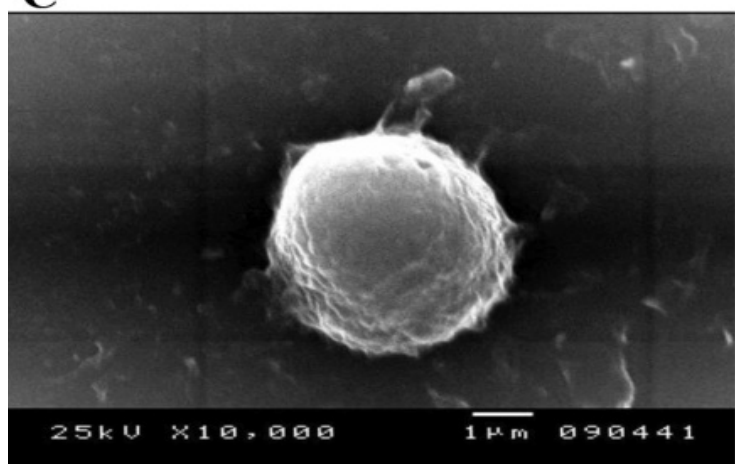

B

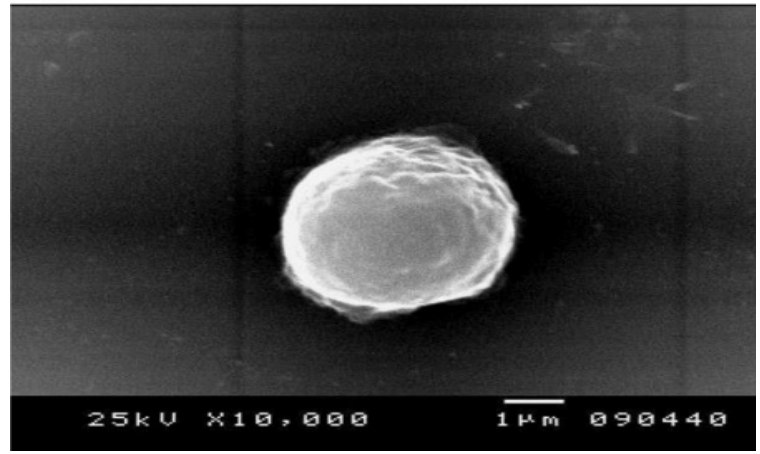

D

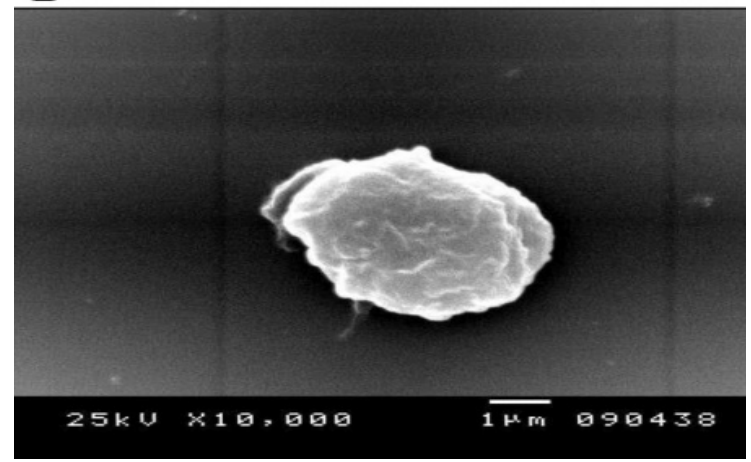

3)

$\mathbf{A}$
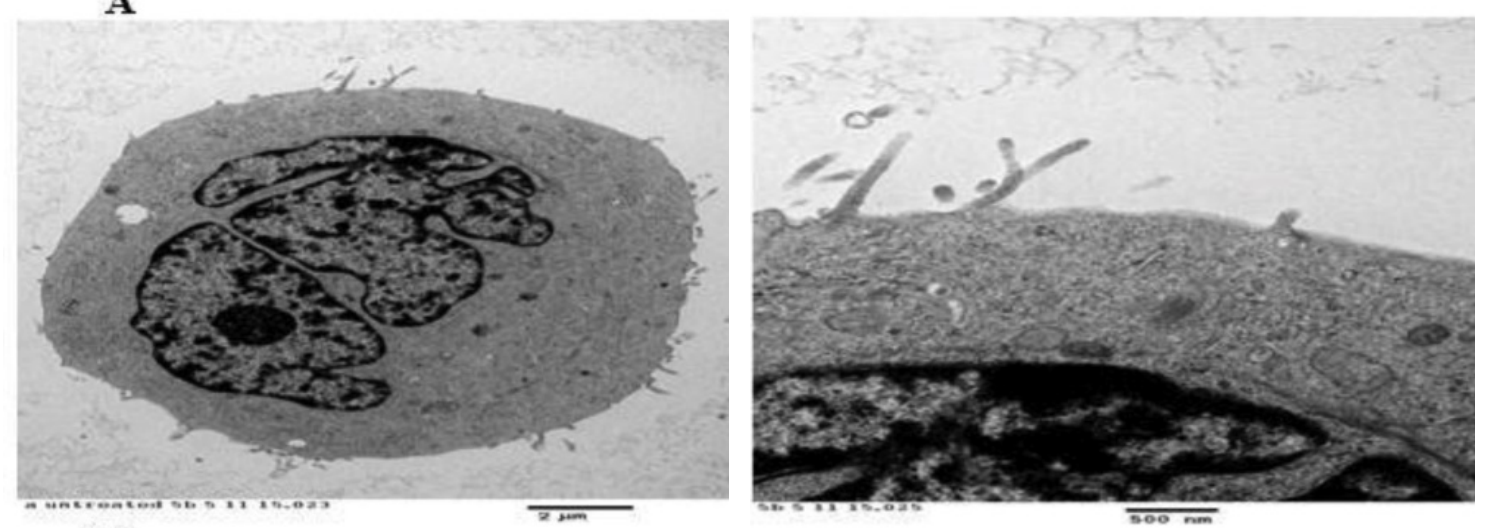

B
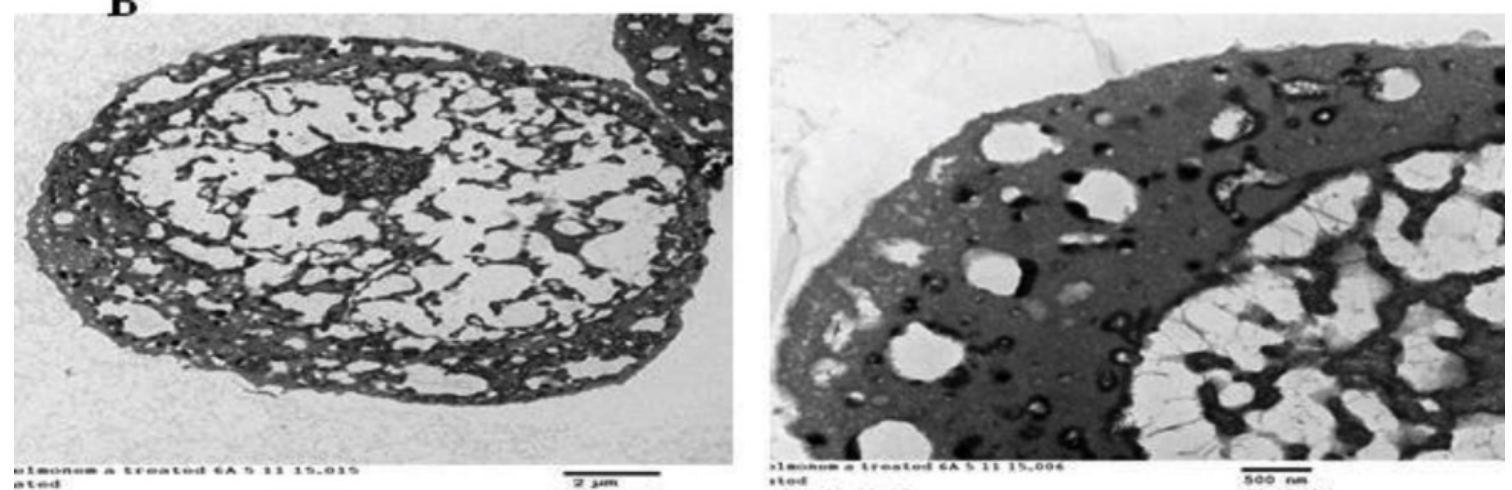

Figure 4. (1) The morphological change of $(A)$ : untreated cells, (B): etoposide, (C): violacein, (D): PC (E): PCB, (F): combinedtreated MCF-7 cells. (2) Scanning electron microscope of (A): untreated cells, (B): violacein, (C) PC, (D) combined-treated MCF7 cells. (3) Transmission electron microscope of (A): untreated cells. (B): combined- treated cells 

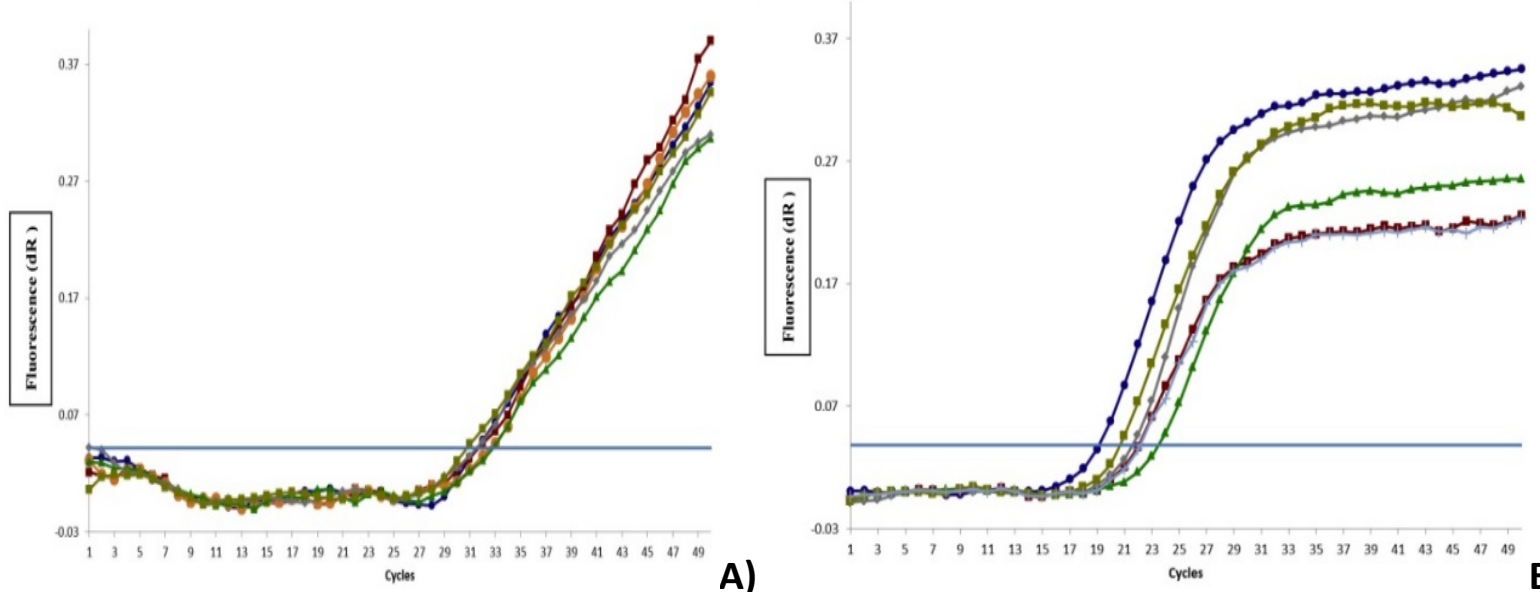

B)
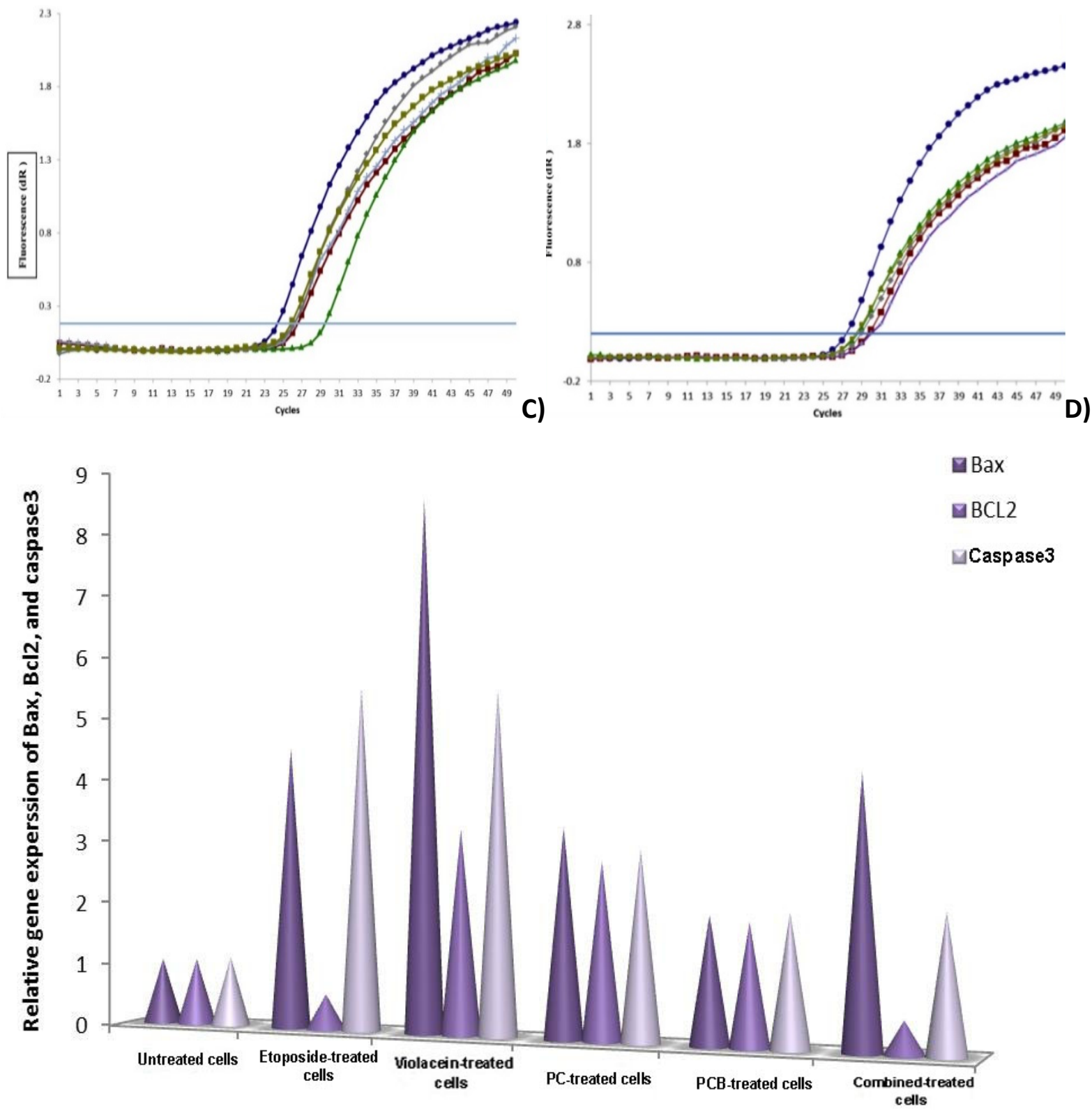

Groups

E)

Figure 5. Amplification plot of (A) Bax, (B) Bcl-2, (C) caspase-3, (D) GDPH expression and (E) genes relative expression in different studied groups. 

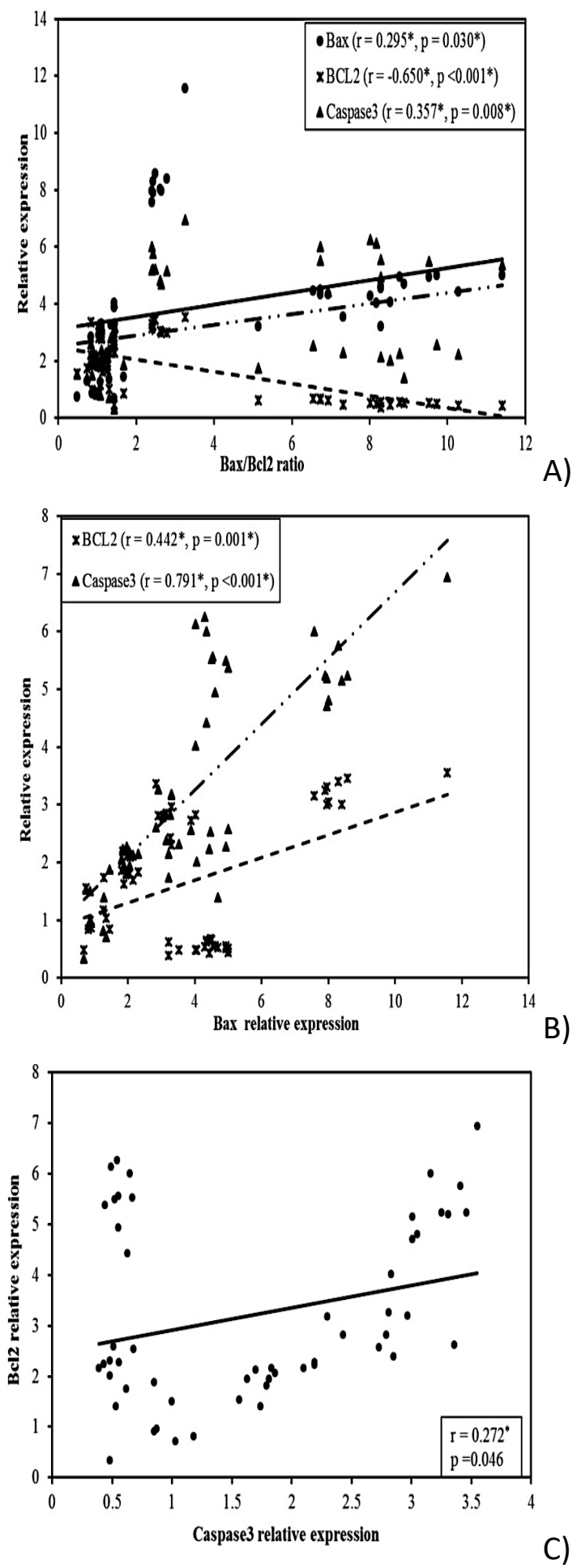

Figure 6. Correlation between the studied genes in total sample $(n=54)$ : (A) Bax/Bcl-2 ratio and Bax, Bcl-2, caspase3; (B) Bax and Bcl-2, caspase-3; (C) caspase-3 and Bcl-2.

induction of mitochondrial apoptotic pathway (intrinsic pathway). On the contrary, PC and PCB-treated cells exerted a significant decrease in Bax, and caspase- 3 expression indicating that $P C$ and $P C B$ have less potent effect than etoposide.
Comparing to violacein-treated cells, all parameters in $\mathrm{PC}, \mathrm{PCB}$, combined-treated cells were significantly decreased except $\mathrm{Bax} / \mathrm{Bcl}-2$ ratio in combined-treated cells which was significantly increased. These results may indicate the high cytotoxicity of violacein on tumor cells through induction of apoptosis. Interestingly, the three genes were significantly decreased in PCB-treated cells than PC-treated cells. Although PC antioxidant activity was attributable to $\mathrm{PCB}$, the possible contribution of apoprotein to the total antioxidant activity of PC could not be excluded since amino acids of the protein may contribute to its antioxidant activity (Madhyastha and Vatsala, 2010).

The significant increase of $\mathrm{Bax}$, and $\mathrm{Bax} / \mathrm{Bcl}-2$ ratio and the significant decrease of $\mathrm{BCl}-2$ by combined therapy than PC or PCB-treated cells may indicate the effectiveness of combined therapy. Besides, violacein-PC combination caused downregulation of $\mathrm{Bax}, \mathrm{Bcl}-2$, caspase-3 as compared to single treatment of either violacein or $\mathrm{PC}$ except for higher Bax expression than PC. An elevated $\mathrm{Bax} / \mathrm{Bcl}-2$ ratio by combined therapy was also observed. These results suggested the combined therapy may exert its apoptotic effect by influencing intrinsic pathway. The combined therapy did not achieve the expected results for caspase- 3 and this may refer to the need of combined therapy for more incubation time to exert its effect.

The correlation between pro-, anti-apoptotic and $\mathrm{Bax} / \mathrm{Bcl}-2$ ratio was reasonable since the apoptotic pathway was activated through Bax/Bcl-2 related caspase-3 activation and preferred cells entry apoptotic pathway. The localizing $\mathrm{Bcl}-2$ and $\mathrm{Bax}$ in the same cells might suggest the two opposing mechanisms that attempt to decide cells fate (Yang et al., 2002) since Bax may modulate $\mathrm{Bcl}-2$ effect and that explain the observed positive correlation between them. Our results proved that all studied compounds induced apoptosis in MCF-7. This observation confirmed by cells morphological alternations which were typical of the apoptosis process.

Despite the improvement in the understanding of cancer genome, the full characteristics of cancer glycoproteome and glycome are still under research. Glycans in cancer are involved 


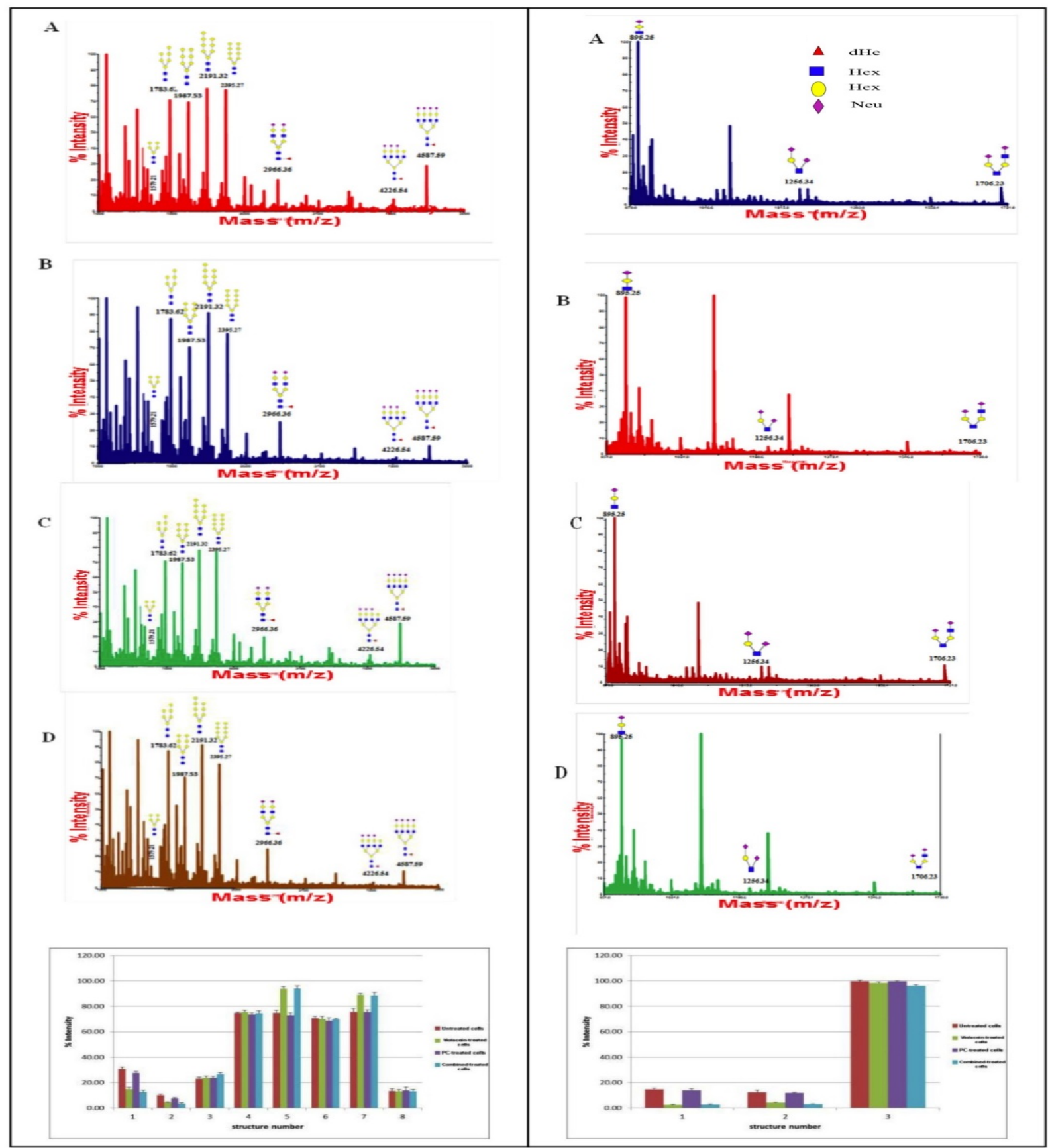

Figure 7. MS profile and intensity \% of N-glycan (left) and O-glycan (right): (A) untreated; (B) violacein; (C) PC; (D) combinedtreated MCF-7 cells.

in essential molecular and cellular processes. Generally sialic acid terminates the outer end of glycans (sialoglycans), and its expression on membrane glycolipids and glycoproteins as well as its secretion into microenvironment is increased in cancer cells (Varki, 2017). Alteration of sialyltransferases activity causes increasing of glycans sialylation, specific tumor associated-carbohydrate antigens, genes of sialic acids biosynthesis, and sialidases activity (Häuselmann and Borsig, 2014).
From glycan profiles, N-/O-glycans structure1,2 intensity was significantly lower in violacein than untreated cells and combined-treated cells than either untreated or PC-treated cells. Furthermore, O-glycan structure3 was significantly decreased in combined therapy compared to either untreated or treated cells.

Cell death resistance is one of the malignant cell characteristics. Down-regulation or mutation of molecules implicated in Fas receptor-Fas ligand 
(FasR- FasL) pathway is an ordinary mechanism utilized by malignant cells to escape apoptosis where cells can hypersialylate FasR (Swindall and Bellis, 2011). FasR acts as a substrate for $\beta$ galactoside $\alpha 2,6$ sialyltransferase (ST6Gal I). In cancer cells, silencing ST6Gal I expression enhances FasL-induced apoptosis, while ST6Gal I overexpression hinders Fas-mediated apoptosis. $\alpha 2,6$-sialylation of FasR impairs its internalization and inhibits the initiation of death-inducing signaling complex (DISC) through preventing Fas-associated adaptor domain (FADD) binds to FasR death domain. Naturally, internalization of FasR results in more DISC structure and serves as a positive feedback loop used for Fas-mediated apoptosis. The FasR sialylation prevents this signal amplification loop and disrupts the downstream apoptotic signaling cascades, thus enabling cancer to deactivate the main apoptotic pathway (Büll et al., 2014). Accordingly, treatment of MCF-7 cells with violacein or combined therapy may have an obvious role in reducing sialylation which favors inducing extrinsic apoptotic pathway. These observations were in line with the obtained genomic results.

The observed high intensity of di-sialylated $\mathrm{N}$ glycan in combined-treated cells only may be due to the specific changes in glycosyltransferase expression that play role in MCF-7 cells glycosylation. Moreover, the raise in some high-mannose $\mathrm{N}$-glycans (structure5,7) intensity proposes the early termination of glycosylation pathway and trouble in their synthesis which prohibits deletion and consequent a supplement of sugar residues. Certainly, variations in the earlier part of a biosynthesis pathway are recognized to increase the number of particular structures besides limit other structures (Varki, 2017). The increased existence of high-level mannose glycans (hybrid-type structures or vis-à-vis complex), has significances for protein functions where they may modify the protein ability to interact with substrates, stability, half-life, communication properties of proteins (De Leoz et al., 2011).

The significantly increased $\mathrm{N}$-/O-glycans structure1,2 concomitant with significantly decreased of structure5,7 in PC-treated cells compared to violacein-treated cells indicate a rise in the glycosylation process which decreases some high mannose $\mathrm{N}$-glycan to produce complex and hybrid oligosaccharides. Alternatively, the other glycan structures showed insignificance difference compared to untreated or violacein-treated cells. This observation may indicate that the treatment with $P C$ is less effective than violacein.

Conclusion: for the first time, this study shows that cotreatment with violacein and PC has antiproliferative and pro-apoptotic effects on MCF-7 cells through the intrinsic and extrinsic pathways. Violacein-PC combination generates a synergistic effect leading to increase in their anticancer activity. Therefore, this combined therapy may be a promising chemotherapeutic applicant for BC.

Anticancer effect of violacein, PC, PCB on MCF7 cells is mediated by apoptosis induction in a caspase-dependent manner. Cancer cells respond to these drugs takes place under genetically programmed mechanisms proves the probability that selective interference in the process which can be modified by a regulated expression of particular genes, as $\mathrm{Bax}, \mathrm{Bcl}-2$, caspase-3 may affect the course of the disease.

Finally, this study yielded some basic information about $\mathrm{N}$-/O-glycans in violacein and/or PC-treated MCF-7 cells. The difference in the intensity of specific glycan structures can indicate their impact on cancer progression. Also, the terminal sialic acid decline suggests its role in cell apoptosis.

\section{Acknowledgements}

We thank Prof. Dr. Yehia Mechref, Director of Genomics and Biotechnology Center, Texas Tech University, Texas, USA for offering MALDITOF-Mass spectrometry.

\section{CONFLICT OF INTEREST}

All authors declared no conflicts of interest.

\section{FUNDING}

No fund was received for this work.

\section{REFERENCES}

Ahmad WA, Yusof NZ, Nordin N, Zakaria ZA, Rezali MF (2012). Production and characterization of violacein by locally isolated Chromobacterium 
violaceum grown in agricultural wastes. Appl Biochem Biotechnol, 167: 1220-1234.

Alshatwi, A.A., Subash-Babu, P., and Antonisamy, P. (2016). Violacein induces apoptosis in human breast cancer cells through up regulation of BAX, p53 and down regulation of MDM2. Exp Toxicol Pathol; 68: 89-97.

Beuhler, R.J., Pierce, R.C., Friedman, L., and Siegelman, H.W. (1979). Cleavage of phycocyanobilin from C-phycocyanin. Separation and mass spectral identification of the products. J Biol Chem; 251: 2405-2411.

Brockhausen, I., and Stanley, P. (2015). O-GalNAc Glycans. In: rd, Varki A, Cummings RD, Esko JD, Stanley P, Hart GW, Aebi M, Darvill AG, Kinoshita T, Packer NH, et al. editors. Essentials of Glycobiology. Cold Spring Harbor (NY).

Büll, C., Stoel, M.A., den, Brok, M.H.and Adema, G.J. (2014). Sialic acids sweeten a tumor's life. Cancer Res; 74: 3199-3204.

Chou, T.C., and Talalayn, P. (1984). Quantitative analysis of dose-effect relationships: the combined effects of multiple drugs or enzyme inhibitors. Adv Enzyme Regul; 22: 27-55.

De Carvalho, D.D., Costa, F.T., Duran, N., and Haun, M. (2006). Cytotoxic activity of violacein in human colon cancer cells. Toxicol In Vitro; 20: 1514-1521.

De Leoz, M.L.A., Young, L.J., An, H.J., Kronewitter, S.R., Kim, J., Miyamoto., et al., (2011). Highmannose glycans are elevated during breast cancer progression. Mol Cell Proteomics; 10: M110.002717.

Demain, L.A., and Vaishnav, P. (2012). Natural products for cancer chemotherapy. Microb Biotechno; 4: 687-699.

Devanathan, J., and Ramanathan, N. (2012). Pigment production from Spirulina platensis using seawater supplemented with dry poultry manure. J Algal Biomass UtIn; 3: 66-73.

Dwarakanath BS, Khaitan D, and Mathur R (2004). Inhibitors of topoisomerases as anticancer drugs: problems and prospects. Indian J Exp Biol; 42: 649-659.

Ferlay, J., Soerjomataram, I., Dikshit, R., Eser, S., Mathers, C., Rebelo, M., et al. (20.15). Cancer incidence and mortality worldwide: sources, methods and major patterns in GLOBOCAN 2012. Int J Cancer;136: 359-86.

Gantar, M., Simović, D., Djilas, S., Gonzalez, W.W., and Miksovska, J. (2012). Isolation, characterization and antioxidative activity of Cphycocyanin from Limnothrix sp. strain 37-21. J Biotechnol; 159: 21-26.

Ghoncheh, M., Mohammadian-Hafshejani, A., and Salehiniya, H. (2015). Incidence and Mortality of Breast Cancer and their Relationship to
Development in Asia. Asian Pac J Cancer Prev; 16: 6081-6087.

Goetz, J.A., Mechref, Y., Kang, P., Jeng, M.H., and Novotny, M.V. (2009). Glycomic profiling of invasive and non-invasive breast cancer cells. Glycoconj J; 26: 117-131.

Häuselmann, I., and Borsig, L. (2014). Altered tumorcell glycosylation promotes metastasis. Front Oncol; 4: 28.

Jiang, J., Li, L., Xie, M., Fuji, R., Liu, S., Yin, X., et al. (2015). SPATA4 counteracts etoposide-induced apoptosis via modulating Bcl-2 family proteins in HeLa cells. Biol Pharm Bull; 38: 1458-1463.

Jiang, L., Wang, Y., Liu, G., Liu, H., Zhu, F., Ji, H., and Li, B. (2018). C-Phycocyanin exerts anti-cancer effects via the MAPK signaling pathway in MDAMB-231 cells. Cancer Cell Int;18: 12.

Jiang, L., Wang, Y., Zhu, F., Liu, G., Liu, H., Ji, H., et al. (2019). Molecular Mechanism of Anti-Cancer Activity of the Nano-Drug C-PC/CMC-CD59sp NPs in Cervical Cancer. J Cancer; 10: 92.

Kang, P., Mechref, Y., Klouckova, I., and Novotny, M.V. (2005). Solid- phase permethylation of glycans for mass spectrometric analysis. Rapid Commun Mass Spectrometry; 19: 3421-3428.

Kang, P., Mechref, Y., and Novotny, M.V. (2008). High-throughput solid-phase permethylation of glycans prior to mass spectrometry. Rapid Commun Mass Spectrom; 22: 721-734.

Konícková, R., Vanková, K., Vaníková, J., Vánová, K., Muchová, L., Subhanová, et al. (2014). Anticancer effects of blue-green alga Spirulina platensis, a natural source of bilirubin-like tetrapyrrolic compounds. Ann Hepatol; 13: 273-283.

Madhyastha, H., and Vatsala, T.M. (2010). Cysteinerich cyanopeptide beta2 from Spirulina fusiformis exhibits plasmid DNA pBR322 scission prevention and cellular antioxidant activity. Indian J Exp Biol. 48: 486-493.

Mechref, Y., Hussein, A., Bekesova, S., Pungpapong, V., Zhang, M., Dobrolecki, L.E., and Novotny, M.V. (2009). Quantitative serum glycomics of esophageal adenocarcinoma and other esophageal disease onsets. J Proteome Res. 8: 2656-2666.

Mohan, J. (2005). Organic spectroscopy principles and applications, $2^{\text {nd }}$ Edn. Narosa publishing House, Daryagani, Delhi.

Mokhtari, B., Homayouni, T.S., Baluch, N., Morgatskaya, E., Kumar, S., Das, B., and Yeger, H. (2017). Combination therapy in combating cancer. Oncotarget. 8: 38022-38043.

Mosmann, T. (1983). Rapid colorimetric assay for cellular growth and survival: application to proliferation and cytotoxicity assays. J Immunol Methods. 65: 55-63. 
Patel, A., Mishra, S., Pawar, R., and Ghosh, P.K. (2005). Purification and characterization of CPhycocyanin from cyanobacterial species of marine and freshwater habitat. Protein Expr Purif. 40: 248-255.

Pfeffer, C., and Singh, A. (2018). Apoptosis: a target for anticancer therapy. Int J Mol Sci. 19: 448.

Romay, C., and Gonzalez, R. (2000). Phycocyanin is an antioxidant protector of human erythrocytes against lysis by peroxyl radicals. J Pharm Pharmacol. 52: 367-368.

Sagar, S., Esau, L., Moosa, B., Khashab, N.M., Bajic, V.B., and Kaur, M. (2014). Cytotoxicity and apoptosis induced by a plumbagin derivative in estrogen positive MCF-7 breast cancer cells. Anticancer Agents Med Chem. 14: 170180.

Santhosh, T.V., and Muthusamy, P. (2017). Evaluation of in vitro cytotoxic effect of violacein produced by novel isolate Chromobacterium Vaccinii CV5 against the cervical and lung cancer cell. Asian J Pharm Clin Res. 10: 227-229.

Saran, S., Puri, N., Dut, Jasuja, N., kumar, M., and Sharma, G. (2016). Optimization, Purification and characterization of Phycocyanin from Spirulina platensis. Int J Appl Pure Sci Agri. 2: 2394-5532.

Schram, B.L., and Kroes, H.H. (1979). Structure of phycocyanobilin. Eur J Biochem. 19: 581-594.

Song, E., Hu, Y., Hussein, A., Yu, CY., Tang, H., and Mechref, Y. (2015). Characterization of the glycosylation site of human PSA prompted by missense mutation using LC-MS/MS. J proteome Res. 14: 2872-2883.
Swindall, A.F., and Bellis, S.L. (2011). Sialylation of the Fas death receptor by ST6Gal-I provides protection against Fas-mediated apoptosis in colon carcinoma cells. J Bio Chem. 286: 2298222990.

Talabnin, K., Talabnin, C., Ishihara, M., Azadi, P., Wongkham, S., and Sripa, B. (2016). Differential expression of O-glycoprotein glycans in cholangiocarcinoma cell lines. Asian Pac J Cancer Prev. 17: 691-695.

Torre, L.A., Bray, F., Siegel, R.L., Ferlay, J., LortetTieulent, J., and Jemal, A. (2015). Global cancer statistics, 2012. CA: a cancer J Clin. 65: 87-108.

Varki, A. (2017). Biological roles of glycans. Glycobiol. 27: 3-49.

Vitek, L., and Schwertner, H.A. (2007). The heme catabolic pathway and its protective effects on oxidative stress-mediated diseases. Adv Clin chem. 43: 1-57.

Wen, P., Hu, T.G., Wen, Y., Linhardt, R.J., Zong, M.H., Zou, Y.X., and Wu, H. (2019). Targeted delivery of phycocyanin for the prevention of colon cancer using electrospun fibers. Food Funct. 19: 1816-1825.

Yang, B., Johnson, T.S., Thomas, G.L., Watson, P.F., Wagner, B., Furness, P.N., and El Nahas, A.M. (2002). A shift in the Bax/Bcl-2 balance may activate caspase- 3 and modulate apoptosis in experimental glomerulonephritis. Kidney Int. 62: 1301-1313.

Yue, Z., Zhang, W., Lu, Y., Yang, Q., Ding, Q., Xia, J., and Chen, Y. (2015). Prediction of cancer cell sensitivity to natural products based on genomic and chemical properties. Peer J. 3: e1425.

Zhang, S.H., and Huang, Q. (2013). Etoposide induces apoptosis via the mitochondrial-and caspasedependent pathways and in non-cancer stem cells in Panc-1 pancreatic cancer cells. Oncol Rep. 30: 2765-2770. 



\section{Egyptian Association for Cancer Research (EACR)}

http://eacr.tanta.edu.eg/

EACR is an NGO society that was declared by the Ministry of Social Solidarity (Egypt) No. 1938 in 19/11/2014 based on the initiative of Prof. Mohamed Labib Salem, the current Chairman of EACR. EACR aims primarily to assist researchers, in particular young researchers in the field of cancer research through workshops, seminars and conferences. Its first international annual conference entitled "Anti-Cancer Drug Discovery" was successfully organized in April 2019 (http://acdd.tanta.edu.eg). Additionally, EACR aims to raise the awareness of the society about the importance of scientific research in the field of cancer research in prediction, early diagnosis and treatment of cancer. EACR is also keen to outreach the scientific community with periodicals and news on cancer research including peer-reviewed scientific journals for the publication of cutting-edge research. The official scientific journal of EACR is "International Journal of Cancer and biomedical Research (IJCBR: https://jcbr.journals.ekb.eg) was successfully issued in 2017 and has been sponsored by the Egyptian Knowledge Bank (EKB: www.ekb.eg).

\section{EACR Chairman,}

Prof. Mohamed Labib Salem, PhD

Professor of Immunology

Faculty of Science, Tanta Universiy, Egypt 


\section{GUIDE FOR AUTHORS}

Publisher :The International Journal of Cancer and Biomedical Research (IJCBR) is an International and interdisciplinary journal of preclinical and clinical studies in the area of cancer and biomedical research. It is a peer-reviewed journal in English, published quarterly (in March, June, September, and December) by the Egyptian Association for Cancer Research (EACR) in both print and online formats (4 issues making a volume). Special issues or supplements may also be produced from time to time upon agreement with the Editorial Board.

Scope :The main aim of IJCBR is to attract the best research in animal and human biology in health and diseases from across the spectrum of the biomedical sciences at the molecular, cellular, organ, and whole animal levels especially those that are related to cancer research, including causes, prediction, diagnosis, prognosis, and therapy.

Publication Fees :The journal does charge for submission, processing, or publication of manuscripts (2000 LE for Egyptians or $250 \$$ for non-Egyptians; EACR members receive 15\% discount on publication). Of them Peer-review fees (300 LE) should be paid on submission (non-refundable). For the fast-track production of the accepted manuscript, another 500 LE is paid.

General specifications for different types of article

- Submitted manuscripts should not have been published previously, except in a limited form (e.g. short communication to a symposium or as part of MSc or PhD theses) and should not be under consideration for publication by other journals.

- All co-authors should agree with the content of the manuscript. Authors must have obtained permission to use any copyrighted material in the manuscript before submission.

IJCBR publishes different types of articles

- Original Article (6000 words with $\mathbf{4}$ tables and $\mathbf{4}$ figures, maximum $\mathbf{8}$ display items): Articles with novel findings are the target of IJCBR. Articles presenting a detailed description of a new technique, comparison of existing methods, meta-analyses with comprehensive and in-depth discussion are considered. Papers in a numbered series are not accepted unless all are submitted at the same time.

- Short communications or case study (3000 words with $\mathbf{4}$ display items): Short communications present exceptionally exciting, novel or timely contents are considered. They will be peer-reviewed in the same way as research papers. The references are restricted to 15 .

- Reviews or systematic review (9000 words with $\mathbf{1 0}$ display items): They are invited by the Editorial Board or unsolicited. Review articles have to be contemporary and comprehensive and add information to the knowledge. Sharp critical analyses of novel data or concepts are encouraged. When relevant, a statistical analysis of data and a meta-analysis approach are recommended.

- Opinion papers, letter to the editor or comment to the editor (1500 words with $\mathbf{2}$ display items): They are submitted by invitation of the Editorial Board. They are short papers, which aim to inform scientists, industry, and the public and policymakers about cutting-edge issues in research or the impact of research. They reflect the opinion of their authors who bear full responsibility of the published paper. The references are restricted to 10 .

- Conference/Symposium papers: The journal will consider for publication the results of original work and critical reviews that are presented at conferences/symposia. Symposium organizers who wish to publish bundles of papers from a symposium/conference in IJCBR should first contact the Editor-in-Chief of the IJCBR (EACR@unv.tanta.edu.eg) for agreement. Supplementary material can be proposed and will be made available online. The responsibility for the preparation of a paper in a form suitable for publication lies with the author.

- Thesis: IJCBR can publish the summary and abstract of Master and PhD theses in a special issue.

English: Good quality of written English is required. Spelling may be in British or American English but must be consistent throughout the paper. Care should be exercised in the use of biological terminology that is ill-defined or of local familiarity only. We recommend that authors have their manuscripts checked by an English language native speaker before submission.

Manuscript layout: Manuscripts should be prepared using a standard word processing program and presented in a clear readable format with easily identified sections and headings. The manuscript layout is based on the following directions.

- The main text contains Title, Abstract, Keywords, Introduction, Material and Methods, Results, Discussion, References, Tables, figures.

- The title needs to be concise and informative. Use bold, with an initial capital for the first word only and for words that ordinarily take capitals.

- Short (running) title (max 80 characters including spacing).

- The article text should be typed with double line spacing with wide margins $(2.5 \mathrm{~cm})$.

- The lines must be continuously numbered; the pages must also be numbered.

- Font Calibri 12 should be used for the text, and 12 for the tables, figure legends and references.

- The sections should typically be assembled in the following order:

- Title page contains title, authors' names, full affiliations, acknowledgements and the corresponding author's contacts and Short title.

Abstract (max 250 words, single paragraph): The abstract should be complete and understandable without citation, references, table, or figure. Use structured abstract: Background, Aim, Materials \& Methods, Results and Conclusion. The context and the rationale of the study are presented succinctly to support the objectives. The experimental methods and main results are summarized but should not be overburdened by numerical values or probability values. The abstract ends with a short and clear conclusion. 
Keywords: Up to five short and specific keywords should complement the title with respect to indicating the subject of the paper in alphabetic order.

Introduction: The introduction briefly outlines the context of the work, presents the current issues that the authors are addressing and the rationale to support the objectives, and clearly defines the objectives.

Material and methods: Material and methods should be described in sufficient details so that others can repeat the experiment. Reference to previously published work may be used to give methodological details, provided that said publications are readily accessible and in English. The code of ethics should be followed for all experiments use animals or human samples.

Statistical analysis of results: The statistical design and the models of statistical analysis must be described, as well as each of the statistical methods used. Sufficient statistical details must be given to allow replication of the statistical analysis. The experimental unit should be defined (e.g., individual or group of animals).

Results: Data are presented as tables and figures. Brief description of the results for each table and figure should be presented. Unpublished data can be mentioned when necessary.

Discussion: Should be separate from the Results section and should focus only on intra- and inter-data discussion (the data in the results section) as well as with the relative data in the literature. Don't repeat information already presented in the Introduction section. Start the first paragraph in the Discussion with a paragraph stating the rationale behind the study, the objectives, and the main findings. End Discussion with a short conclusion.

Acknowledgements: In this section, the authors may acknowledge (briefly) their support staff.

Conflict of interest: All papers with a potential conflict of interest must include a description/explanation in a separate heading.

Funding details: The authors should state the source of findings of the study (with research funder and/or grant number). If no fund, the authors should state that the study is self-funded.

\section{References}

Citation of references: In the text, references should be cited by the author(s) surname(s) and the year of publication (e.g. Salem, 2020). References with two authors should be cited with both surnames (e.g. Salem and Meshrif, 2021). References with three or more authors should be cited with the first author followed by et al. (in italics; e.g. Salem et al., 2021). Names of organizations used as authors (e.g. Food and Drug Administration) should be written out in full in the list of references and on the first mention in the text. Subsequent mentions may be abbreviated (e.g. FDA).

- List of references. Literature cited should be listed in alphabetical order by authors' names. It is the author's responsibility to ensure that all references are correct. All authors should be written and so the full journal name.

- $\quad$ References from journal articles are formatted in APA as this example: Al-Amoudi WM (2018). Toxic effects of Lambdacyhalothrin on the rat thyroid. Involvement of oxidative stress and ameliorative effect of ginger extract. Toxicology Reports, 5: 728-736.

- $\quad$ References from books or official reports are formatted as this example. Kebreab E, Dijkstra ANM, Bannink A, Gerrits WJJ, \& France J (2006). Nutrient digestion and utilization in farm animals. CABI Publishing. Wallingford, UK.

- References from chapters or parts of books are formatted as this example. Nozière $P, \&$ Hoch $T$ (2006). Modelling fluxes of volatile fatty acids from rumen to portal blood. In: Nutrient digestion and utilization in farm animals (Kebreab E, Dijkstra ANM, Bannink A, Gerrits WJJ \& France J, eds.), pp. 40-47. CABI Publishing. Wallingford, UK.

Tables: The data should be presented in tables or in graphs, not both.

- Each table should be placed on a separate page at the end of the main text.

- Tables are numbered consecutively using Arabic numbering. They are referred to as Table 1 , Table 2, etc., with capital ' $T$ ', no italics

- $\quad$ Each table has its explanatory caption. The caption is sufficient to permit the table to be understood without reference to the text.

- Abbreviations used in tables/figures have to be defined either as footnotes or in the caption.

\section{Figures}

- $\quad$ Package the figures in a single PowerPoint file. Each figure in a separate slide.

- Figure size should be readable in a width of approximately 8-175 $\mathrm{mm}$ (i.e. the maximum size of printing over two columns).

- Ensure that the font size is large enough to be readable at the final print size, use Calibri font to ensure that they are consistent throughout the figures.

- $\quad$ The figures should preferably be provided as TIFF or EPS files.

- The resolutions of figures must be at least $300 \mathrm{dpi}$.

- Preparation of images for a manuscript: For guidance, we refer to the Journal of Cell Biology's instructions to authors (http://jcb.rupress.org/site/misc/ifora.xhtml\#image_aquisition).

- If a cropped image is included in the main text of a paper (e.g. a few lanes of a gel), display the full original image, including the appropriate controls, the molecular size ladder and/or the scale as relevant, as a single figure in a Supplementary Material file to facilitate peer-review and for subsequent online publication.

- Supplementary material is submitted along with the main manuscript in a separate file and identified at uploading as "Supplementary File - for Online Publication Only" The title of the article is included at the top of the supplementary material.

Corresponding author's guidelines: Upon acceptance the corresponding author is required to send his/her recent formal photo to be attached to the front page of the article. 


\title{
International Journal of Cancer \& Biomedical Research
}

(IJCBR) Online ISSN 2682-2628

\author{
Editor-in-Chief \\ Mohamed Labib Salem, PhD \\ Tanta University, Egypt
}

\begin{tabular}{l} 
EACR Board \\
\hline Nehal Elmashad, MD \\
Tanta University, Egypt \\
Nabil Mohy Eldin, PhD \\
Kafrelsheikh University, Egypt \\
Doaa Al-Ghareeb, PhD \\
Alexandria University, Egypt \\
Abdel-Aziz Zidan, PhD \\
Damanhour University, Egypt
\end{tabular}

\begin{tabular}{l} 
Managing Editor \\
\hline Wesam Meshrif, PhD \\
Tanta University, Egypt \\
Sohaila Galal, PhD \\
Tanta University, Egypt \\
Production and Contact \\
\hline Hamdi Kandil \\
Tanta University, Egypt \\
Email: ljcbr100@gmail.com
\end{tabular}

\section{Advisory Board}

Alberto Montero, MD

Taussig Cancer Center, Cleveland,

USA

Yi Zhang, MD

Zhengzhou University, China

Mark Robunstein, Ph D

Medical University of South

Carolina, USA

Mohsen Farid, Ph D

Derby University, USA

Natarajan Muthusamy, Ph D

Ohio State University, USA

Hideki Kasuya, MD

Nagoya University, Japan

Sherif El-Khamisy, Ph D

Sheffield University, UK

Mohamed Ghanem, Ph D

Kafr Elshikh University, Egypt

Sayed Bakry, Ph D

Alazhar University, Egypt

Sameh Ali, Ph D

Nationa Liver Institute, Egypt

Gamal Badr, Ph D

Assuit University, Egypt

Nadia Hamdy, Pharm D

Ain Shams University, Egypt

\section{Editorial Board}

\section{Clinical studies}

Hesham Tawfik, MD

Tanta University, Egypt

Mohamed Attia, MD

Tanta University, Egypt

Mohamed Elshanshory, MD

Tanta University, Egypt

Essam Elshiekh, MD

Tanta Cancer Center, Egypt

Rasha Eraky, MD

Tanta University, Egypt

Shaima Abou-Kjatwa, MD

Tanta University, Egypt

Marcela Diaz, MD

Cleveland Clinic Foundation, USA

Mohamed Abou-El-Enein, MD

Charité Universitätsmedizin Berlin,

Germany
Alaa Eldin Almostafa, MD

McGill University, Canada

Olfat Gadallah, MD

Tanta University, Egypt

Nagla Sarhan, MD

Tanta University, Egypt

Naglaa Fathy, Pharm D

Zagazik University, Egypt

Mohamed Salama, MD

Mansoura University, Egypt

Mona Marie, MD

Alexandria University, Egypt

Preclinical studies

Mostafa El-Sheekh

Tanta University, Egypt

El-Refai Kenawy, Ph D

Tanta University, Egypt

Mohamed Noureldin, Ph D

Banaha University, Egypt

Yousry Albolkiny, Ph D

Tanta University, Egypt

Elsayed Salim, Ph D

Tanta University, Egypt

Shengdian Wang, Ph D

Chinese Academy of Sciences,

China

Sabry El Naggar, Ph D

Tnata Univesity, Egypr

Faris Alenzi, Ph D

Prince Sattam bin Abdulaziz

University, KSA

Ibrahim El-Sayed, Ph D

Menoufia University, Egypt

Tarek Aboul-Fadl, Ph D

Assiut University, Egypt

Rabab Khairat, Ph D

National Research Center,

Giza, Egypt

Wael Lotfy, Ph D

Alexandria University, Egypt

Ashraf Tabll, Ph D

National Research Center, Egypt

Nahla Shoukry, Ph D

Suez University, Egypt
Medhat Eldenary, Ph D

Tanta University, Egypt

Azza Hasan, Ph D

Menufia University, Egypt

Nanees Gamal Eldin, Ph D

Tanta University, Egypt

Mohamed Mansour, UK

Sabbah Hammoury, Ph D

Alexandria Ayadi Almostaqba

Oncology Hospital, Egypt

Nehal Aboulfotoh, Ph D

Zewail City for Science and

Technology, Cairo, Egypt

Amir Elkhami, Ph D

Galaxo, San Francisco, USA

Ahmed Alzohairy, Ph D

Zagazi University, Egypt

Wgady Khalil, Ph D

National Research Center, Egypt

Amr Amin, Ph D

United Arab Emirates

University, UAE

AbdelRahman Zekri, Ph D

National Cancer Institute, Egypt

Hussein Khamis, Ph D

Alexandria University, Egypt

Magdy Mahfouz, Ph D

Kafr Elsheikh University, Egypt

Ehab Elbedewey, Ph D

Tanta University, Egypt

Abeer Badr, Ph D

Cairo University, Egypt

Mamdooh Ghoneum, Ph D

Charles Drew University of

Medicine \& Science, USA

Haiam Abou Elela, Ph D

National Institute of Oceanography and Fisherie, Egypt

Maha EL-Demellawi, Ph D City for Scientific Research \&

Technology Applications, Egypt

Desouky Abd-El-Haleem, Ph D

City for Scientific Research \&

Technology Applications, Egypt 